\title{
Legislating Stock Prices
}

\section{Citation}

Cohen, Lauren, Karl Diether, and Christopher Malloy. "Legislating Stock Prices." Harvard Business School Working Paper, No. 13-010, July 2012.

\section{Permanent link}

http://nrs.harvard.edu/urn-3:HUL.InstRepos:9369297

\section{Terms of Use}

This article was downloaded from Harvard University's DASH repository, and is made available under the terms and conditions applicable to Open Access Policy Articles, as set forth at http:// nrs.harvard.edu/urn-3:HUL.InstRepos:dash.current.terms-of-use\#OAP

\section{Share Your Story}

The Harvard community has made this article openly available.

Please share how this access benefits you. Submit a story.

Accessibility 

H A R V A R D
B U S I N E S S
S C H O O L

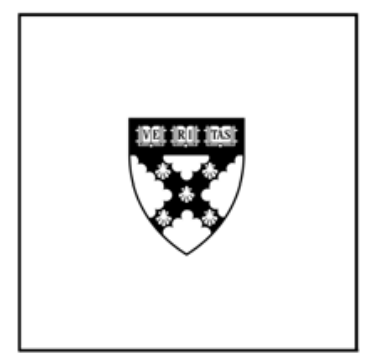

\section{Legislating Stock Prices}

Lauren Cohen

Karl Diether

Christopher Malloy

\section{Working Paper}

\section{3-010}

July 31, 2012 


\title{
Legislating Stock Prices*
}

\author{
Lauren Cohen \\ Harvard Business School and NBER
}

Karl Diether

Dartmouth College

Christopher Malloy

Harvard Business School and NBER

* We would like to thank Yakov Amihud, Jonathan Berk, Simon Gervais, Roni Michaely, Daniel Paravisini, Andrei Shleifer, Clemens Sialm, Pietro Veronesi, and seminar participants at Jane Street Capital, the IDC Conference in Herzliya, and the Western Finance Association (WFA) meeting in Las Vegas for helpful comments and suggestions. We are grateful for funding from the National Science Foundation. 


\begin{abstract}
In this paper we demonstrate that legislation has a simple, yet previously undetected impact on firm stock prices. While it is understood that the government and firms have an important relationship, it remains difficult to determine which firms any given piece of legislation will affect, and how it will affect them. By observing the actions of legislators whose constituents are the affected firms, we can gather insights into the likely impact of government legislation on firms. Specifically, focusing attention on "interested" legislators' behavior captures important information seemingly ignored by the market. A long-short portfolio based on these legislators' views earns abnormal returns of over 90 basis points per month following the passage of legislation. Further, the more complex the legislation, the more difficulty the market has in assessing the impact of these bills. Consistent with the legislator incentive mechanism, the more concentrated the legislator's interest in the industry, the more informative are her votes for future returns.
\end{abstract}


An important but understudied relationship that impacts firms is the one between firms and the government. Specifically, governments pass laws that affect firms' competitive environment, products, labor force, and capital, both directly and indirectly. While this relationship is well-understood, it is often difficult to determine which firms any given piece of legislation will affect, and how it will affect them. However, we do observe the behavior of agents with a direct interest in the firms affected by legislation. By observing the actions of legislators whose constituents are the affected firms (its employees, suppliers, other local stakeholders, etc.), we can gather insights into the likely impact of government legislation on firms. Specifically, focusing attention on the legislators who have the largest vested interests in firms affected by a given piece of legislation gives a powerful lens into the impact of that legislation on the firms in question; a lens that the market does not appear to be gazing through.

It turns out that very rich data exists on the behavior of legislators. Legislator voting behavior is public and detailed going back decades for both chambers of the U.S. Congress (the Senate and House of Representatives). Further, this data gives a fair amount of power in that each firm (by definition) is headquartered in at least one legislator's constituency, but for each firm and industry being affected by a given bill there will be a large group of "un-interested" legislators to compare against. There are enough "un-interested" legislators that are alike in nearly every other dimension (partyaffiliation, ideology, voting on all other bills, etc.) that we can form very fine control groups to tease out solely the part of legislators' voting behaviors that is driven by their direct interest in a given firm or industry.

If the market does not fully incorporate the information in legislator behavior to infer each bill's full effect on firms, then that leaves rich, important information for firms' underlying values that is unincorporated into market prices. The advantage of this approach is that we can use the actions of legislators to predictably identify the subsequent impact of each law on each firm.

An important issue will of course be how much of a bill's impact on firm values is already incorporated by the market into firms' prices. To answer this question, we show that there is almost no run-up in terms of firm returns in the 6- (or 12-) month period 
prior to the bill's passage. Additionally, and interestingly, there are zero abnormal returns in the month that the bill is actually passed. Only over the post-passage period does the market sluggishly begin to realize the impact of the bill for firm values.

The measurement of which firms are materially impacted by a given bill is at the crux of this paper. As mentioned above, we measure this by using the simple but powerful method of listening closely to only those legislators who have a vested interest in the given bill. We identify interests by the amount of economic activity in that legislator's state that is likely affected by the bill in question. Specifically, we look at number of firms, number of employees, and aggregate size of firms, for each industry in each state, and assign each legislator's interests based on these measures. We focus on industries rather than firms as only very rarely can a legislator put language into a bill that solely affects an individual firm (empirically, we only see this a handful of times in our 20 year sample of all legislation). This may be for cosmetic reasons, or simply because a legislator often has many firms from a given industry in her state, and so does not want to appear to favor one, at the perceived detriment to others. This also may be impacted by (or be the driver behind) most powerful lobbying groups (which we measure and discuss later in the paper) forming at the industry level.

Given that our classification scheme of bills (described in Section II) assigns affected industries to bills based on the text of the bill regarding each industry, we can then see how these "interested" legislators vote versus uninterested legislators on each respective bill. Given that these interested and uninterested legislator groups change for each bill depending solely on industry, this forms finely specified treatment and control groups that allow us to control for other voting determinants, and identify solely this vested interest impact on each vote.

We then simply see whether interested legislators are more positive or more negative for the bill (relative to the uninterested control group). If the interested legislators vote more in favor of a bill covering their vested industries than uninterested legislators, we code this as a positive bill for the underlying industry. If they vote more negatively for a bill that passes ${ }^{1}$ than uninterested legislators, we code this as a negative

\footnotetext{
${ }^{1}$ We limit to bills that pass as these are the bills that have the potential to actively change the regulatory
} Legislating Stock Prices - Page 4 
bill for the industry.

Using this simple method, we show that a long-short portfolio of industry returns in the month following the passage of a bill where we listen solely to vested interest legislators (i.e., long the affected industries when interested senators are especially positive about the bills passing, and short the affected industries when interested senators are especially negative about the bills passing), yields returns of 76 basis points per month. These returns are virtually unaffected by controls for known risk determinants. For example, the four-factor alpha of this long-short portfolio yields abnormal returns of 92 basis points $(t=3.01)$ per month, or over 11 percent per year.

As mentioned above, we see no run-up in returns before the bill passage, and no abnormal return in the announcement month. Further, the large abnormal returns that we document in month $t+1$ continue to accrue for a number of future months, suggesting that this interested legislator behavior does contain important information for underlying firm values. Collectively, these results are consistent with the market having difficulty in deciphering the information contained in bills for future firm value. More strikingly, the market does not seem to be taking into account the seemingly simple information in the vested interest legislators voting on these exact bills following bill passage, when it is completely in the public domain.

One alternative explanation is that any simple manner in which you code these bills may lead to abnormal returns if the market is truly ignoring the legislation. There may be nothing special, then, about isolating those legislators with the largest vested interests, per se. To get a feel for this, we look at two other logical methods to see their ability to pick up this same information for firm values. If you believe that legislators on average bring positive bills to passage to help their constituent industries, then a simple strategy of longing the industries when bills about them pass, and shorting industries when bills about them fail, would yield abnormal returns. A second, more nuanced method, uses the text of the bill itself along with established dictionaries of positive and negative words, to classify each bill as positive or negative for an industry. We construct

environment for the treated firms. We understand that bills that fail also likely contain information for firms even if they keep the status-quo regulatory regime (if the market probabilistically weights the likelihood of passage), and we show evidence on these, as well. 
both of these measures, and find that neither the more naïve strategy nor the textual analysis strategy have any predictive ability over firm returns. ${ }^{2}$ Thus, it appears to be something unique about exploiting the incentives and vested interests of legislators that gives an especially informative measure of the impact of bills on firm values.

We also conduct a number of tests designed to isolate the mechanism driving our main results. For example, if we truly are identifying important information in interested legislators' behaviors for future firm values, then if we could find even more concentrated interests, these accompanying legislators should have even more informative behavior. We approach this idea in several ways. The first is to measure concentrated interests by looking at legislators whose largest state industry (e.g., oil) also makes up a large fraction of their total state's economic activity. We find, consistent with more concentrated interests being even more informative, that the long-short portfolio following these especially concentrated vested legislators yields four-factor abnormal returns of 105 basis points per month $(t=2.37)$.

The second way we link these returns more directly to the interests of legislators is by looking at how important the given bill is for each industry mentioned in the bill. Although a number of industries may be mentioned in a given bill, a bill may largely focus on a single industry and only peripherally touch on a number of others. If legislator interest really is the driving force behind our return results, we should see the most informative votes being those most directly impacted by the bill; thus, the industry that dominates the bill's text. When we focus on the voting of solely the interested legislators who are impacted by the most dominant industry in the bill, the long-short portfolio returns rise to 130 basis points per month $(t=2.78)$, or $15.6 \%$ per year. To focus even further on these most important mentioned industries, we also look solely at those firms in the most important mentioned industry who are headquartered in interested legislators' states. The idea here is that legislators, while not able to mention specific firms, still can have some latitude to focus industry-wide legislation in a way that most benefits the firms in their states (e.g., loosening offshore drilling regulations, while keeping oil fracking regulations constant). While this reduces the sample size quite a bit,

\footnotetext{
${ }^{2}$ It is important to note that we again see no pre-vote run up, nor any announcement effects, using either of these two measures to classify positive legislation and negative legislation for firms.
} 
the effect on the magnitude is large: the long-short portfolio has returns of 184 basis points per month $(t=1.89)$.

To explore the question of what allows the return predictability we document to persist, we also examine the complexity of the bills in question. Specifically, we test the idea that the market may have a harder time deciphering the likely impact of a complicated bill as opposed to a simpler bill, and hence we should observe more return predictability following the passage of complex bills. Using the number of times a bill is voted on as a measure of bill complexity, we show that the spread portfolio on complex bills earns large positive abnormal returns (ranging from 85 basis points in raw returns $(t=2.19)$ to 90 basis points $(t=2.28)$ in four-factor alphas), while the set of non-complex bills is associated with much smaller (and insignificant) return predictability, consistent with the idea that the market has more difficulty processing the likely impact of complicated pieces of legislation as opposed to more routine bills.

We also examine the impact of lobbying on our results. The motivation behind this test is that when see industry lobbying organizations spending large amounts of money, it presumably is to sway the opinion of legislators. If this works, and if lobbyists spend even part of this money outside of states that already have a vested interest in the law (which is not unreasonable, given that constituent interest may be a substitute for this, and so the marginal lobbying may be better spent on a legislator who does not already have a vested interest), then we would expect formerly "uninterested" legislators to be treated by lobbyists, so in a sense to now become somewhat "interested." This reduces the distance between our "interested" and "uninterested" legislator measure (as some of the previously uninterested legislators are now interested), and so reduces the power and predictability of the measure. We find exactly this to be true: when industry lobby groups have large amounts of spending in a given year, the predictability of our measure of interested versus uninterested legislators by simply location of economic activity drops by almost half.

As a final robustness check, we show that the effect we document has actually gotten stronger over time: in the more recent period, the magnitudes of the return effects are $15-20 \%$ larger. 
The remainder of the paper is organized as follows. Section I describes the setting and related literature. Section II describes the data. Section III presents the main portfolio and regression results. Section IV explores the mechanism in more detail. Section $\mathrm{V}$ presents additional examining lobbying expenditures and our main results. Section VI concludes.

\section{Related Literature}

Our paper adds to a vast literature that studies the impact of government policies on firms. While a large literature studies the impact of government actions (e.g., spending policies) on broader state-level outcomes (see, for example Clemens and Miran (2010), Chodorow-Reich, et al. (2010), Wilson (2011), Fishback and Kachanovskaya (2010), Serrato and Wingender (2011) and Shoag (2011)), our approach in this paper is closest to a recent strand of the literature that explores firm-level outcomes. These papers examine the benefits that firms perceive (and receive) from currying favor and/or making connections with politicians, such as higher valuations (Roberts (1990), Fisman (2001), Jayachandran (2006), Faccio (2006), Faccio and Parsley (2006), Fisman et. al (2007), Goldman et. al (2007)), corporate bailouts and government intervention (Faccio et. al (2006), Duchin and Sosyura (2009), Tahoun and Van Lent (2010)), and lucrative procurement contracts (Goldman et. al (2008)). ${ }^{3}$ Our focus in this paper is on all Congressional legislation, not simply budget bills or spending polices, and our outcome variable of interest is the stock returns of affected firms. In this sense, our paper is also related to a recent literature examining the impact of government policy on asset prices (Pastor and Veronesi (2012), Belo, Gala, and Li (2012)). Our approach in this paper is unique in that we focus on politician-level voting behavior and bill-level legislation in order to identify the impact of legislation on firms.

Finally, since our empirical strategy relies on the idea that firm-level constituent interests affect Congressional voting, our paper is also related to a large literature studying the factors that influence the behavior of elected officials. Much of this

\footnotetext{
${ }^{3}$ See also Cohen, Coval, and Malloy (2011) for evidence on the impact of state-level earmark spending on firm-level outcomes such as investment and employment, and Julio and Yook (2012) who document that corporate investment varies with the timing of national elections around the world.
} 
literature (see, for example, Stigler (1971) and Peltzman (1985)) argues that political party and constituent interests are key determinants of politicians' voting behavior. Hibbing and Marsh (1991), Stratmann (2000), Pande (2003), Chattopadhyay and Duflo (2004), and Washington (2007) also provide evidence that personal characteristics such as service length, age, religion, race, gender, and the presence of a daughter in one's family can affect the behavior of elected officials. Finally, a variety of papers stress the importance of political ideology in explaining Congressional voting behavior (see Clinton, Jackman, and Rivers (2004), Kau and Rubin (1979, 1993), Lee, Moretti, and Butler (2004), McCarty, Poole and Rosenthal (1997), McCarty, Poole and Rosenthal (2006), and Poole and Rosenthal (1985), (1997), (2007)). Meanwhile, Levitt (1996), Ansolabehere et.

al (2001), Synder and Groseclose (2000), Kalt and Zupan (1990), and Mian et. al (2009) provide a number of different perspectives on separating out the impact of ideology versus party interests, constituent interests, and special interests. Since our interested and uninterested legislator groups change for each bill depending solely on industry, this forms finely specified treatment and control groups that allow us to control for other voting determinants, and identify solely this vested interest impact on each vote.

\section{Data and Summary Statistics}

We combine a variety of novel data sources to create the sample we use in this paper. Our primary source of data is the complete legislative record of all Senators and all Representatives on all bills from the 101st through 110th Congresses. We collect this from the Library of Congress' Thomas database. Each "Congress" is two years long, and is broken into two one-year-long "Sessions." Therefore, 10 Congresses represents twenty years of Congressional data from 1989-2008. We collect the result of each roll call vote for the twenty-year period in each chamber of the Congress, and record the individual votes for every Congressman voting on the bill (or abstaining). We choose to start with the raw bill data, rather than use alternate, publicly available versions of the Congressional roll call data (see, for example, the Voteview website, as well as McCarty, Poole and Rosenthal (1997), McCarty, Poole and Rosenthal (2006), Poole and Rosenthal (1985), (1997), (2007), among many others), or the Political Institutions and Public Choice (PIPC) House Roll Call Database (Aldrich, Brady, de Marchi, McDonald, Nyhan, 
Rohde, and Tofias (2008)), because we exploit the text of each piece of legislation as described below.

A key aspect of our empirical strategy is that we utilize the content of the bills being voted on. To do so, we download the full text of all bills being voted on over our sample. We collect the full-text data jointly from the websites of the Government Printing Office (GPO), and from the Thomas database. As in Cohen and Malloy (2011), we then parse and analyze the full bill text to classify each bill into its main purpose. For our tests, we attempt to assign each bill to one (or more) of the 49 industry classifications used in Fama and French (1997). ${ }^{4}$ To do this we first construct a set of keywords for each industry. We then create an executable (shown in Figure A1), in which we input all bills and their corresponding full-text and assign bills to industries based on the count of the number of times these keywords appear in a given bill. We only assign a bill to an industry if the number of instances of a particular keyword exceeds a certain threshold of frequency on a given bill relative to its overall frequency in the entire population of bills. ${ }^{5}$ Individual bills can be assigned to more than one industry; however, we use a conservative assignment procedure such that our procedure only results in industry assignments of any kind for less than $20 \%$ of all bills, and specifically only those bills where we can confidently gauge that an industry is likely to be affected by the bill in question. Figure A1 presents an example of a particular bill that was assigned only to the Fama-French industry \#30: Petroleum and Natural Gas, based on the relative frequency of pre-specified keywords in the bill that pertain to this industry. Figure A1 displays the summary text at the top of the bill, which indicates that the bill clearly pertains to the oil and gas industry. The data Appendix provides more details on our bill assignment procedure. We have compared our bill categorizations to those used in other work (see, for example, Aldrich, Brady, de Marchi, McDonald, Nyhan, Rohde, and Tofias (2008), among others), but prefer our approach because it achieves our explicit goal of assigning each bill to the specific industries (and thus firms) that are potentially affected, rather than to the specific policy issues under consideration.

\footnotetext{
${ }^{4}$ The "Fama-French 49" industry definitions map specific 4-digit SIC (standard industry classification) codes to 49 different industry categories, and are publicly available online from:

http://mba.tuck.dartmouth.edu/pages/faculty/ken.french/.

${ }^{5}$ We have experimented with various thresholds, and our results are not sensitive to the particular threshold we employ. Please see the Appendix for more details on our bill classification procedure.
} 
Importantly, our empirical approach in this paper also requires us to "sign" the impact of each bill, as positive or negative, for the given industry it affects. We do so by exploiting the voting record of those Senators who are likely to identify it as a relevant industry to their constituents. To identify the constituent interests of a given Senator, we assign each firm domiciled in a Senator's home state to one of the Fama-French 49 industries; "relevant" industries to a particular Senator on a particular bill are those industries that: i.) are assigned to that bill using the procedure described above, and ii.) have at least one firm headquartered in the Senator's home state that belongs to the given industry. We then rank all the industries in each Senator's state by aggregating all firms in each industry by size (sales and market cap), and define "important" industries as those that rank in the top three for each state in terms of size. Next we sign each bill by looking at the voting records of those Senators who have "important" industries that are mentioned in the bill; we term these Senators as "interested" Senators, and term all the remaining Senators as "uninterested" Senators. The rationale behind this procedure is that a Senator's vote on a particular bill that affects important firms in his state is likely to suggest how that bill will affect those firms in his state; thus we can infer that a yes vote by a Senator with a vested interest in a bill is likely to mean that the bill is positive for the industry he cares about, and vice versa for a no vote.

Figure A2 displays the executable program we created to implement our signing procedure for the same bill depicted in Figure A1. The summary text indicates that the goal of this bill is "to provide energy price relief and hold oil companies and other entities accountable for their actions with regard to high energy prices, and for other purposes," so the bill is likely to be perceived as negative for the oil and gas industry. And not surprisingly, even though this vote lined up largely along party lines, none of the 6 Republican Senators who voted in favor of the bill were Senators who were "tied" to this industry via constituent interests in their home state (all 8 industry-tied Republicans voted against), and 1 of the 2 Democrats who voted against the bill was Mary Landrieu of Louisiana, a state heavily represented by oil and gas interests (the other Democrat who voted against was Henry Reid from Nevada, a consistent supporter of oil and gas companies); the 6 industry-tied Democrats who voted in favor of the bill did so largely on party and ideological grounds (variables that we control for in our tests, as described 
below).

Specifically, we "sign" each bill's expected impact on a given industry by comparing the votes of "interested" Senators on that bill to the votes of "uninterested" Senators on that bill. Again, interested Senators on a given bill are those where an industry affected by the bill is a "Top 3" industry in that Senator's home state (where industries are ranked within each state by total aggregate firm sales, or total market capitalization). We then compute an Economic Interest signing measure as follows: we compute the ratio of positive votes of all interested Senators by dividing their total number of yes votes on a bill by their total number of votes, and compare this to the ratio of positive votes of all uninterested Senators; if the ratio of positive votes by interested Senators is greater than that for uninterested Senators, we call this a "positive" bill for the industry in question, and if the ratio of positive votes for interested Senators is less than that for uninterested Senators, we call this a "negative" bill for the industry. Our results are very similar regardless of whether we use this ratio difference ("R-R" in Figure A2) measure, or alternative signing measures such as the absolute ratio ("Ratio" in Figure A2, i.e., the percentage of industry-tied Senators who vote for the bill), or the relative ratio (" $\mathrm{R} / \mathrm{R}$ " in Figure $\mathrm{A} 2$, i.e., the percentage of industry-tied Senators who vote for the bill divided by the percentage of all Senators who vote for the bill). and the ratio difference ("R-R" in Figure A2, i.e., the percentage of industry-tied Senators who vote for the bill minus the percentage of all Senators who vote for the bill); our results are not sensitive to the particular signing measure we employ. We have also tried within-party signing measures that are computed identically to those above, except aggregated within each party (since many votes are along party lines) and again the results are very similar. The data Appendix contains more details on our signing procedure. ${ }^{6}$

For some of our ancillary tests, we also hand-collect lobbying data from the OpenSecrets.org website (sponsored by the Center for Responsible Politics). Finally, we draw monthly firm-level stock returns, shares outstanding, and volume capitalization from CRSP, and extract firm-specific accounting variables, such sales, research and

\footnotetext{
${ }^{6}$ The data Appendix provides more details about the industry assignment keywords, procedure, cut-offs,
} etc. 
development (R\&D) expenditures, capital expenditures (CAPEX), and book equity, from Compustat.

Table I presents summary statistics from our sample. As Table I shows, over 82 percent of bills in our sample pass. As a result, for a given bill, an average of 73 votes are "Yea" votes. For our Top 3 classification of "interested" Senators, the average number of Yea votes is around 8. Finally, the mean industry-level value-weight return over our sample period (199001-200812) is 78 basis points per month.

\section{Results}

\section{A. Portfolio Returns on Nä̈ve Classifications}

Our primary tests examine the impact of legislation on the stock returns of industries affected by a given bill. Since our bill assignment procedure is at the industrylevel (rather than at the firm-level, since individual firms are rarely mentioned in bills), we compute the value-weighted returns to all 49 Fama-French industries, and use these value-weight industry returns as our outcome variables.

We begin by examining the returns to a naïve strategy for signing the direction of impact of legislation on the underlying affected industries. Specifically, in Panel A of Table II we perform a calendar-time portfolio approach as follows: for each final Senate vote on a bill, we examine the stock returns of affected firms following the passage or failure of the bill. We form a "Long" portfolio that buys the firms in each industry that we assign to a bill (weighted by market capitalization) when the bill passes, and a "Short" portfolio that sells the firms in each industry that we assign to a bill (weighted by market capitalization) when the bill fails. Affected stocks do not enter the portfolio until the month following the passage of a bill, and portfolios are rebalanced monthly. Panel A reports the average monthly "Long-Short" portfolio return for a portfolio that goes buys the "Long" portfolio and sells the "Short" portfolio each month. The "CAPM alpha" is a risk-adjusted return equal to the intercept from a time-series regression of the Long-Short portfolio on the excess return on the value-weight market index (see Fama and French (1996)). The "Fama-French alpha" is a risk-adjusted return equal to the intercept from a time-series regression of the Long-Short portfolio on the excess return on the value-weight market index, the return on the size (SMB) factor, and the return on 
the value (HML) factor (see Fama and French (1996)). The "Carhart alpha" is a riskadjusted return equal to the intercept from a time-series regression of the Long-Short portfolio on the excess return on the value-weight market index, the return on the size (SMB) factor, the return on the value (HML) factor, and the return on a prior-year return momentum (MOM) factor (see Carhart (1997)).

As Panel A shows, the returns to this naïve strategy for signing bills are essentially zero. Also, there does not appear to be any price run-up in the period prior to and including the month of passage/failure of a bill, as the long-short portfolio return in the pre-vote period (using returns from months $t-6$ to $t$, where month $t$ is the month of passage/failure) is also negligible. This suggests that on average there is no new information in whether a bill passes or fails regarding how these bills will impact the underlying firms.

Our next set of tests uses a slightly more nuanced approach for determining the impact of legislation on firms. Specifically, in Panels B and C, we focus on the set of bills that ultimately passed, and attempt to "sign" each bill using different forms of textual analysis. In Panel B, we form a "Long" portfolio that buys the firms in each industry that we assign to a bill (weighted by market capitalization) when the bill contains a below-median number of negative words (defined using the Harvard psychosocial dictionary (see Tetlock (2007)), and a "Short" portfolio that sells the firms in each industry that we assign to a bill (weighted by market capitalization) when the bill contains an above-median number of negative words. Panel $\mathrm{C}$ conducts the identical tests as in Panel B, except that negative words are defined using alternative definition categories (see Loughran and McDonald (2011)).

Panels $\mathrm{B}$ and $\mathrm{C}$ show that in both the post-passage period (month $t+1$ ) and in the pre-vote period (months $t-6$ to $t$, where month $t$ is again the month of passage), there is no impact on the returns of the underlying affected industries. Thus, trying to infer the impact of legislation on firms by using textual analysis that seeks to measure the "negativity" of a bill is unhelpful in trying to sign a bill's likely impact. This is perhaps not surprising given the way bills are typically written, in that they are legal documents that are less likely to easily convey sentiment. Thus the findings in Table II help to motivate our approach, since simple methods for inferring the likely impact of legislation 
on firms reveal no systematic impact in terms of returns, both in the period leading up to a bill's passage, and in the period immediately after a bill's passage.

\section{B. Economic Interest Portfolio Returns}

Table III presents our key result. Rather than using a naïve signing approach, or a signing approach based on textual analysis, we simply use the votes of "interested" Senators as a vehicle for determining the likely impact of a piece of legislation. Specifically, as noted above, we "sign" each bill's expected impact on a given industry by comparing the votes of "interested" Senators on that bill to the votes of "uninterested" Senators on that bill. Recall that interested Senators on a given bill are those where an industry affected by the bill is a "Top 3" industry in that Senator's home state (where industries are ranked within each state by total aggregate firm sales). We then compute an Economic Interest signing measure as follows: we compute the ratio of positive votes of all interested Senators by dividing their total number of yes votes on a bill by their total number of votes, and compare this to the ratio of positive votes of all uninterested Senators; if the ratio of positive votes by interested Senators is greater than that for uninterested Senators, we call this a "positive" bill for the industry in question, and if the ratio of positive votes for interested Senators is less than that for uninterested Senators, we call this a "negative" bill for the industry. We then form a "Long" portfolio that buys the firms in each industry that we assign to a bill (weighted by market capitalization) where the Economic Interest signing measure is positive, and a "Short" portfolio that sells the firms in each industry that we assign to a bill (weighted by market capitalization) where the Economic Interest signing measure is negative. In Panel A of Table III, affected stocks do not enter the portfolio until the month following the passage of a bill, and portfolios are rebalanced monthly.

Panel A of Table III shows that the Long/Short portfolio based on this strategy earns large abnormal returns. Using excess returns, CAPM alphas, 3-factor alphas, or 4factor alphas, the Long/Short portfolio consistently earns large abnormal returns, ranging from 76 basis points per month $(t=2.44)$ to 92 basis points per month $(t=3.01)$. Most of

this spread comes on the short side, with the abnormal returns to the short portfolio ranging from 71 to 83 basis points per month ( $t=2.40$ and $t=2.80$, respectively), 
suggesting that focusing on cases when interested Senators are disproportionately negative with respect to a bill that ultimately passes is particularly profitable. This result suggests that simply by focusing on the votes of interested Senators, one can determine the subsequent impact of legislation after its passage, and that the market does not recognize this impact. ${ }^{7}$

Panels B and C of Table III then examine the returns to these industry portfolios in the months leading up to and including the month of passage. Again there is little evidence of run-up in the pre-period, and also virtually no effect in the month of passage, suggesting that the market's response to the information in legislation is indeed delayed.

\section{Announcement Effects and Event-Time Returns}

Table III examined the six months leading up to the bill, the month of passage, and the month following the passage of the bill. From Table III, there did not appear to be any significant run-up in pre-passage returns (i.e., probabilistic revelation of passage of the bill). In Figure 1, we examine more closely the days leading up to (and following) the passage of the bill, and extend the window to six months following bill passage. Figure 1 shows the event-time Cumulative Abnormal Returns (CARs) to the spread (Long-Short) portfolio returns (equivalent to Column 3 of the panels in Table III). CARs are computed for each side of the portfolio individually using market-adjusted returns, with the figure showing the returns to the spread portfolio of these CARs.

First, from Figure 1 there seems to be little run-up in the days leading up to the passage of the bill, as the average CAR from day -10 to 0 is only 4 basis points. Importantly, following passage of the bill, the returns then significantly drift upward for the next three months (60 days), then flatten, and remain flat thereafter.

Note that uncertainty leading up to the vote could impact this return pattern in Figure 1. Thus, close votes may see less of a return run-up, but then have an amplified initial return (passage-day return), as the uncertainty is resolved. However, the median bill in our sample from Table III and Figure 1 passes with a wide margin: 85 yea votes. Even the $25^{\text {th }}$ percentile has 69 yea votes, suggesting we simply do not have that

\footnotetext{
7 We have also computed this Economic Interest signing measure within party (i.e., comparing an interested Senator's vote only to the other uninterested Senator's within her party). The raw spread is actually slightly larger using this measure, 88 basis points per month $(t=3.26)$.
} 
many bills that had much uncertainty of passage leading up to the vote. Even with these non-close votes, we are finding that the average bill (which is not a close vote) appears to have very little pre-passage run-up in return, and has returns that drift upward for a long period of time following passage. Thus, the delayed updating to information shown in Figure 1 appears to have little to do with the closeness of the vote, or the immediate updating of a previously uncertain vote outcome. Instead, it is more consistent with the market not fully understanding and taking into account the economic interests of the legislators involved, their impact on voting behavior, and the resulting impact of legislation on firms.

\section{Short Side Returns}

One of the interesting aspects of Panel A of Table III is that most of the return predictability seems to be coming through the short side of the portfolio. That is to say, the bills where interested senators seem to be especially negative relatively to uninterested senators seem to result in the large, significantly negatively future returns that comprise most of the long-short portfolio return. A trading-cost friction (i.e., shortsale constraint) argument for the pattern seems a bit less plausible here than in many studies, as we are trading using simple value-weighted industry returns. ${ }^{8}$ We thus do a number of things to examine these returns in more depth.

First, we simply examine all months of signals for the long and short portfolios. The results in Table III report only those calendar months where both a long and short signal exist. There can be months where solely a bill on which interested senators were more positive passed (a long), or solely a bill on which interested senators were more negative passed (a short). When looking at all months, we do begin to see modest predictability on the positive side. When using all of the months (161 and 175 for the long and short sides, respectively), as opposed to the 155 where both exist, the Carhart four-factor alpha is 34 basis points a month $(t=1.76)$ on the long side, relative to the 14 basis points from Table III. The short side alpha is 75 basis points $(t=2.76)$, nearly identical to that in Table III.

8 We value-weight across industry returns by total industry market capitalization in the portfolio construction, which (although it does not necessarily need to be the case) ends up empirically placing an even larger weight on larger capitalization stocks. 
To further explore this, though, we next examine the relative "positivity" or "negativity" of interested senators on the bills in question. For Table III, we code bills as good or bad for the industry (long or short) based simply if interested senators are more positive or more negative than the rest of the senate. It turns out that senators are much more negative on bad bills than they are positive on good bills, which may explain why the negative bills predict much lower future returns for the associated industries. For instance, on bills negative for the industry interested senators are on average 19.37\% more negative, while being only $12.00 \%$ more positive on good bills. The difference of 7.37 percentage points is highly significant $(\mathrm{p}<0.01)$. The difference exists throughout the distribution with the $75^{\text {th }}$ percentile of negativity being $27.35 \%$ (versus $17.02 \%$ for positivity), and the $95^{\text {th }}$ percentile being $61.96 \%$ more negative (but only $34.83 \%$ more positive). The difference in relative voting behavior on good versus bad bills for industries suggests that a continuous measure of the difference in voting behavior between interested and uninterested senators, as opposed to the discrete relative measure from Table III, may better capture the impact of voting differences. This is precisely what we implement in Section D below (Table IV).

\section{E. Cross-Sectional Regressions}

Next we employ monthly Fama and Macbeth (1973) cross-sectional regressions each month of industry-level returns on industry-level characteristics, to further assess the predictive power of our economic interest signing approach. Unlike with individual stock returns, however, which exhibit well-known size (Banz (1981)), book-to-market ((Rosenburg. Reid, and Lanstein (1985), Fama and French (1992)), and momentum (Jegadeesh and Titman (1993), Carhart (1997)) effects, there is much less evidence of return predictability in industry returns. There does appear to be industry momentum (see Grinblatt and Moskowitz (1999)), and as such we control for industry-level momentum (i.e., the industry return from months $t-12$ to $t-2$ ) in our regression tests. We also include controls on the right-hand size for one-month past industry returns, and measures of industry-level average size, book-to-market, investment (CAPEX), and assets.

Table IV presents the results of these monthly cross-sectional predictive 
regressions. The dependent variable is the value-weighted future industry return (in month $t+1)$. The variable of interest in these regressions is Interested Vote, which is the difference between the percentage of interested senators voting in favor of the passed bill and uninterested senators voting in favor of the bill. So, Interested Vote is positive when interested senators are more in favor of the bill, and negative when interested senators are more negative on the bill.

Column 1 of Table IV shows that interested senators' votes have significant predictive ability for future industry returns, with the coefficient on Interested Vote being $0.025(t=3.03)$. This indicates that the more positive interested senators are relative to uninterested senators on the given bill, the higher the future returns are for affected industries of the bill, consistent with the results in Table III. Controlling for industry momentum, as well as industry-level measures of size, book-to-market, investment, and assets, has little effect on this result. In the full specification in Column 5, Interested Vote has a coefficient of $0.037(t=2.30)$. This implies that a one standard deviation higher Interested Vote (interested senators voting roughly $10 \%$ more in favor of the bill than uninterested senators) implies a 37 basis point higher return for the industries impacted by the bill. These findings reinforce the results from Table III with a continuous measure, also demonstrating that our economic interest signing approach is not simply picking up industry-level characteristics.

Lastly, up to this point we have focused on those bills which pass, as these are the bills that have the potential to actively change the regulatory environment for the treated firms. We understand that bills that fail could also contain information for firms even if they keep the status-quo regulatory regime (if the market probabilistically weights the likelihood of passage). However, as evidence against this probabilistic price revelation, both Table III and Figure 1 indicate that there is no run-up in returns in the months (or days) leading up to the passage of these bills. Nonetheless, we explicitly examine failed bills using our economic interest signing, as well. First, there are only 20 percent as many failed bills as there are bills that pass, likely reflecting the fact that bills expected to fail are simply not brought up for vote. For these failed bills, we replicate the exact specifications of Table IV, with our economic interest signing now measured as interested senators' negative voting relative to how negative non-interested senators vote on the 
same bill (so the predicted sign on Interested Vote is again positive). In the analog to the full specification of Column 5 in Table IV, the coefficient on Interested Vote is 0.023 $(t=0.79)$. Thus, we find that while the direction of the coefficient is as predicted, the magnitude is about two-thirds the size of that of votes passed, and not statistically significant, as we might expect given the continuity of regulatory regime.

\section{Tests of the Mechanism: Concentrated Interests, Industry Relevance, and Bill Complexity}

In this section we explore a variety of ancillary tests in order to help pin down the mechanism behind our main result.

\section{A. Concentrated Interests}

We start by refining our economic interest signing measure even further. The idea behind our first test is that the voting behavior of a particular subset of interested Senators may be even more informative than the voting behavior of the entire group of interested Senators. In particular, focusing on the Senators that have "concentrated" interests in a particular industry may be especially informative.

In Table $\mathrm{V}$ we perform the same calendar-time portfolio tests as in Table III, except that we employ a slightly different signing measure. Rather than looking at all interested Senators, in Panel A we focus only on the voting behavior of Senator's whose largest industry (by market capitalization) ${ }^{9}$ represents an above-median level of concentration in that state relative to all other states that have that industry during that time period. Concentration is measured as the share of a state's total market cap that is made up of the industry in question. The idea is that these Senators will have an even greater vested interest in the fortunes of this particular industry as compared to the other significant industries in their states; hence their voting signals on the bills that affect these particular industries may be quite informative. Table $\mathrm{V}$ shows that this hypothesis is confirmed in the data. The value-weight industry returns that accrue to the

\footnotetext{
${ }^{9}$ All of the results in this section are identical if sales are used in place of market capitalization.
} 
Long/Short portfolio using this refined signing measure are again large and significant, ranging from 67 to 97 basis points per month. Further, in Panel B when we replace the "above-median" relative level of concentration with an $80 \%$ relative level of concentration (as shown in Panel B), this result is even stronger: the Long/Short portfolio earns between $84(t=1.99)$ and $105(t=2.27)$ basis points in this specification. This result suggests that focusing on the Senator's with the largest vested interests does improve the signal about the likely impact of the bill in question.

\section{B. Industry Relevance and Home State Firms Only}

In Table VI we exploit variation in our industry assignment procedure. Specifically, we exploit the idea that some bills may pertain mainly to a particular industry, even though a few industries may be coded as "affected" by a given bill. So while our industry assignment procedure (as described above, and in the Appendix) is quite conservative in ensuring that only affected industries are coded as such, there is still variation in the extent to which one industry may be affected by a bill relative to another industry. In Table VI we exploit this variation in two ways. First, in Panel A we focus solely on cases where the industry in question is the "most" affected of all industries in a given bill; in these cases we only use these industries to compute our industry-level valueweighted return. Panel A shows that exploiting this variation again strengthens the main result, yielding a Long/Short portfolio return ranging from 92 to 130 basis points per month. In Panel B we refine this measure even further by only including the returns of those firms in a given industry who happen to be also located in one of the "interested" Senators home states. Panel B shows that this refinement strengthens the result even further: the Long/Short portfolio return in this specification ranges from 174 to 201 basis points per month.

\section{Complex Bills}

To further explore the mechanism driving our findings, we also explore the complexity of the bills in question. Specifically, we test the idea that the market may have a harder time deciphering the likely impact of a complicated bill as opposed to a simpler bill, and hence we should observe more return predictability following the passage 
of complex bills. ${ }^{10}$ One issue with identifying the complexity of bills is that it does not have a one-to-one mapping with the length of the bill. This is because many routine annual bills (e.g., routine appropriations bills) are among the longest bills. Thus, in order to identify complex bills so as to minimize this problem, we simply compute the number of times a given bill was voted on, with the idea that more complicated bills tend to get voted on more often. It turns out that while this measure is positively correlated (0.28) with the number of words in each bill, it captures rich variation unrelated to simple bill length.

In Table VII, we exploit this variation in bill complexity and re-run our baseline portfolio tests from Table III. In Panel A, we focus solely on the set of complex bills, where complex is defined as a bill that was voted on more times than the median bill (the median number of votes on a bill is 2). Panel A shows that the economic interest spread portfolio earns large positive abnormal returns, ranging from 85 basis points in raw returns $(t=2.19)$ to 90 basis points $(t=2.28)$ in four-factor alphas. Meanwhile, Panel B shows that the set of non-complex bills (the complement of the sample used in Panel A) is associated with much smaller (and insignificant) return predictability, consistent with the idea that the market has more difficulty processing the likely impact of complicated pieces of legislation as opposed to more routine bills.

\section{Robustness: Sub-periods and Economic Interest Thresholds}

In Table VIII we explore a series of additional tests that help to establish the robustness of our main result, and help to verify some obvious implications of our findings. We start by splitting our sample in half, and examining the findings over these two sub-periods (199001-199912, and 200001-200812). Panel A of Table VIII shows that our main result is large in magnitude in both sub-periods, but is somewhat stronger in the more recent sub-period.

In Panel B of Table VIII we test an implication of our empirical strategy, namely that as we broaden our measure of "interested" Senators, our approach should work less well. For example, if we focus on the votes of Senators where any of her Top 5 (or Top

\footnotetext{
${ }^{10}$ See Cohen and Lou (2012) for evidence of substantial return predictability from a set of easy-to-analyze (standalone) firms to their more complicated (conglomerate) peers.
} 
10) industries in her state (as opposed to Top 3) industries are affected by a given bill, we would expect this signal to be somewhat less informative, since these "extra," smaller industries may be less important to the Senator in question. Panel B shows again that this implication is confirmed in the data, as focusing on the votes of Senators using a Top 5 filter yields a smaller but still significant effect (ranging from 56 to 62 basis points per month), and using a Top 10 filter yields an insignificant effect.

Overall, the tests in Table V-VIII help to establish the robustness of the main result in this paper, by showing that logical alterations of our basic economic interest signing approach yield results in the expected directions; when we broaden our signing approach, the results are weaker, and when we refine our approach, the results are stronger.

\section{Other Influences: Lobbying}

In this final section, we explore an additional potential influence on the voting behavior of Senators, in addition to the firm-level economic interest approach that we have utilized throughout this paper. Specifically, we employ data on lobbying expenditures.

Table IX presents the results of tests seeking to explore the impact of this "other influence" on the strength of our economic interest signal. The lobbying data we use (obtained from OpenSecrets.org) unfortunately is not available at the level of a given piece of legislation, but is instead available only by industry and by year, and only since 1999. In Panel A of Table IX we first replicate our main result (from Table III) over the sample period for which lobbying data is available (199901-200812), and verify that our findings are large and significant over this sub-period as well.

We then examine the subset of affected industries for which lobbying is most pronounced in a given year (above the $80^{\text {th }}$ percentile of industries in terms of lobbying dollar expenditures). ${ }^{11}$ Our hypothesis is that the results should be weaker for these industries, since we do not know to whom these lobbying dollars are flowing. Thus our set of interested Senators may no longer be the full set of "interested" Senators; one would want to include all the Senators that received lobbying dollars from a given

\footnotetext{
${ }^{11}$ Using an above-median threshold yields similar results.
} 
industry as now potentially treated, or "interested" in the given industry. In fact, one would expect lobbying dollars to be more likely to go to the other Senators (our "uninterested" Senators), since lobbyists would not need to waste money lobbying the interested Senators who already are going to vote to protect the industry in question. This reduces the distance between our "interested" and "uninterested" legislator measure (as some of the previously uninterested legislators are now interested), and so reduces the power and predictability of the measure. Panel B of Table IX shows that this conjecture is indeed confirmed in the data: the Long/Short portfolio return ranges from 44 to 65 basis points per month and is no longer significant when we focus solely on the affected industries for whom lobbying is most pronounced.

\section{Conclusion}

In this paper we demonstrate that legislation has a simple, yet previously undetected impact on firm prices. Specifically, legislators who have a direct interest in firms often vote quite differently than other, uninterested legislators on legislation that impacts the firms in question. Taking a simple approach of listening more closely to the more incented legislators yields a portfolio that has large outperformance. Longing the industries following the passage of related bills that interested legislators are especially positive about relative to uninterested legislators (and shorting industries in the contrasting case), yields abnormal returns of over 90 basis points per month. These returns show no run-up prior to bill passage and no announcement effect directly at bill passage. Further, the returns continue to accrue past the month following passage. Collectively, these findings suggest that we are truly capturing information from these interested legislators important for firm value; information the market does not seem to be realizing.

We go on to provide more evidence on the proposed mechanism of interested legislators. For instance, these abnormal returns are larger when we focus solely on the industries that make up an especially large part of the economic activity in a legislator's state. Further, the returns are also higher when we restrict to solely the most important industries (i.e., the industries that are likely to be most impacted), and the returns are larger still when we focus within this industry on those firms located solely in interested 
legislators' states. In addition, the return predictability we document is large and significant for complicated bills, but much less so for routine bills, consistent with the idea that the market has a much harder time deciphering the likely impact of complicated pieces of legislation relative to more mundane bills. Lastly, when industry lobbying groups spend large amounts of capital, likely lobbying legislators outside of the states where the industry is already important, this dampens the predictive impact of "interested" legislators, as would be expected given that now what we classify as geographically uninterested legislators will have been treated by the lobbying firms to become "interested." Finally, the effect we document in the paper has, if anything, been becoming stronger over time.

In sum, government's impacts on firms are incontrovertible. In this paper, we formalize an important channel of this relationship, and test whether this relationship and its impact is fully understood and incorporated by financial markets. We believe there is a broader implication of our work regarding the critical importance of firms' relationships with their legal and political environment, and the actors who form this environment. 


\section{References}

Aldrich, John, Michael Brady, Scott de Marchi, Ian McDonald, Brendan Nyhan, David Rohde, and Michael Tofias, 2006, Party and constituency in the U.S. Senate, 19332004, in Why Not Parties?, Nathan W. Monroe, Jason M. Roberts, and David Rohde, eds., University of Chicago Press.

Banz, Rolf W., 1981, The relationship between return and market value of common stocks, Journal of Financial Economics 9, 3-18.

Belo, Frederico, Vito Gala, and Jun Li, 2012, Government spending, political cycles and the cross-section of stock returns, Journal of Financial Economics (forthcoming).

Carhart, Mark M., 1997, On persistence in mutual fund performance, Journal of Finance 52, $57-82$.

Chattopadhyay, Raghabendra and Esther Duflo (2004). "Women as Policy Makers: Evidence from a Randomized Experiment in India." Econometrica, 72, 5, 1405-1443.

Chodorow-Reich, Gabriel, Laura Feiveson, Zachary Liscow, and William Woolston, 2010, Does state fiscal relief during recessions increase employment? Evidence from the American Recovery and Reinvestment Act, Working paper, UC-Berkeley.

Clemens, Jeffrey and Stephen Miran, 2010, The effects of state budget cuts on employment and income, Working paper, Harvard University.

Clinton, Joshua, Simon Jackman, and Douglas Rivers (2004), The statistical analysis of roll call voting: A unified approach, American Political Science Review 98, 1-16.

Cohen, Lauren, Joshua Coval, and Christopher Malloy, 2011, Do powerful politicians cause corporate downsizing, Journal of Political Economy 119, 1015-1006.

Cohen, Lauren, and Dong Lou, 2012, Complicated firms, Journal of Financial Economics 104.

Cohen, Lauren, and Christopher Malloy, 2011, Friends in high places, Working paper, Harvard University.

Duchin, Ran, and Denis Sosyura (2009), TARP Investments: Financials and Politics, Working Paper, University of Michigan.

Faccio, Mara, 2006, Politically connected firms, American Economic Review 96, 369-386.

Faccio, Mara, Ronald W. Masulis, John J. McConnell, 2006, Political connections and corporate bailouts, Journal of Finance 61, 2597-2635. 
Faccio, Mara, and David Parsley, 2006, Sudden death: Taking stock of political connections, Working paper.

Fama, E. and MacBeth, J., 1973, Risk, return and equilibrium: empirical tests, Journal of Political Economy 81, 607-636.

Fama, Eugene F., and Kenneth R. French, 1992, The cross-section of expected stock returns, Journal of Finance 46, 427-466.

Fama, Eugene F., and Kenneth R. French, 1996, Multifactor explanations of asset pricing anomalies, Journal of Finance 51, 55-84.

Fama, Eugene F., and Kenneth R. French, 1997, Industry Costs of Equity, Journal of Financial Economics 43, 153-193.

Fishback, Price V., and Valentina Kachanovskaya, 2010, In search of the multiplier for federal spending in the States during the Great Depression, NBER Working Paper No. 16561.

Fisman, Raymond, 2001, Estimating the value of political connections, American Economic Review 91, 1095-1102.

Fisman, David, Raymond Fisman, Julia Galef, and Rakesh Khurana, 2007, Estimating the value of connections to Vice-President Cheney, Working paper, Columbia University.

Goldman, Eitan, Jorg Rocholl, and Jongil So, 2007, Do politically connected board affect firm value, Review of Financial Studies (forthcoming).

Goldman, Eitan, Jorg Rocholl, and Jongil So, 2008, Political connections and the allocation of procurement contracts, Working paper, Indiana University.

Grinblatt, Mark, and Tobias Moskowitz, 1999, Do industries explain momentum?, The Journal of Finance 54, 1249-1290.

Hibbing, John and David Marsh (1987). "Accounting for the Voting patterns of British MP's on Free Votes." Legislative Studies Quarterly, 12, 2, 275-297.

Jayachandran, Seema, 2006. "The Jeffords effect." Journal of Law and Economics 49, $397-425$.

Jegadeesh, N., 1990, Evidence of predictable behavior of security returns, Journal of Finance 45, 881-898.

Jegadeesh, N., and Titman S., 1993, Returns to buying winners and selling losers: Implications for stock market efficiency, Journal of Finance 48, 65-91. 
Julio, Brandon, and Youngsuk Yook, 2012, Political uncertainty and corporate investment cycles, Journal of Finance 67, 45-83.

Kalt, Joseph P. and Mark A. Zupan, 1990. "The Apparent Ideological Behavior of Legislators: Testing for Principal-Agent Slack in Political Institutions," Journal of Law and Economics, Vol. 33, No. 1 (Apr.), pp. 103-131.

Kau, J.B. and Rubin, P.H., 1979, Self-interest, ideology, and logrolling in congressional voting, Journal of Law and Economics 22, 365-384.

Kau, J.B. and Rubin, P.H., 1993. "Ideology, voting and shirking." Public Choice 76, 151-172.

Lee, D., Moretti, E. and M. Butler 2004. "Do voters affect or elect policies? Evidence from the US House." Quarterly Journal of Economics, 119(3) pp. 807-859.

Levitt, Steven (1996). "How Do Senators Vote? Disentangling the Role of Voter Preferences, Party Affiliation and Senator Ideology." American Economic Review, 86, 3, 425-441.

Levitt, Steven, and James Snyder, Jr., 1995, Political Parties and the Distribution of Federal Outlays, American Journal of Political Science 39, 958-980.

Loughran, Timothy, and William McDonald, 2011, When is a liability not a liability? Textual analysis, dictionaries, and 10-Ks, Journal of Finance 66, 35-65.

Mayhew, David R. (1991). Divided We Govern: Party Control, Lawmaking, and Investigations , 1946-1990. New Haven: Yale University Press.

McCarty, Nolan M., Keith T. Poole, and Howard Rosenthal. 1997. Income Redistribution and the Realignment of American Politics, American Enterprise Institute Press.

McCarty, Nolan M., Keith T. Poole, and Howard Rosenthal. 2006. Polarized America: The Dance of Political Ideology and Unequal Riches, MIT Press.

Nakamura, Emi, and Jon Steinsson, Fiscal stimulus in a monetary union: Evidence from U.S. regions, Working paper, Columbia University.

Pande, Rohini (2003) "Can Mandated Political Representation Increase Policy Influence for Disadvantaged Minorities? Theory and Evidence from India." American Economic Review 93:4, 1132-1151.

Pastor, Lubos and Pietro Veronesi, 2012, Uncertainty about government policy and stock prices, Journal of Finance (forthcoming).

Peltzman, Sam. 1985. "An Economic Interpretation of the History of Congressional Voting in the Twentieth Century." American Economic Review 75 (September), 656-75.

Poole, Keith T. and Howard Rosenthal. 1985. "A Spatial Model for Legislative Roll Call 
Analysis." American Journal of Political Science, 357.384.

Poole, Keith T. and Howard Rosenthal. 1996. "Are Legislators Ideologues or the Agents of Constituents? European Economic Review, 40: 707-717.

Poole, Keith T. and Howard Rosenthal. 1997. Congress: A Political-Economic History of Roll Call Voting. Oxford: Oxford University Press.

Poole, Keith T. and Howard Rosenthal. 2007. Ideology and Congress. Piscataway, N.J.: Transaction Press.

Rohde, David (1953-2004). Roll Call Voting Data for the United States House of Representatives, 1953-2004. Compiled by the Political Institutions and Public Choice Program, Michigan State University, East Lansing, MI, 2004.

Roberts, Brian, 1990, A dead Senator tells no lies: Seniority and the distribution of federal benefits, American Journal of Political Science 34, 31-58.

Rosenberg, Barr, Kenneth Reid, and Ronald Lanstein, 1985, Persuasive evidence of market inefficiency, Journal of Portfolio Management 11, 9-17.

Serrato, Juan Carlos Suarez, and Philippe Wingender, 2011, Local fiscal multipliers, Working paper, UC-Berkeley.

Shoag, Daniel, The impact of government spending shocks: Evidence on the multiplier from state pension plan returns, Working paper, Harvard University.

Snyder, James (1992). "Artificial Extremism in Interest Group Ratings." Legislative Studies Quarterly 17, 3, 319-345.

Snyder, James and Tim Groseclose (2000). "Estimating Party Influence in Congressional Roll-Call Voting." American Journal of Political Science, 44, 2, 193-211.

Stigler, G., 1971. "The theory of economic regulation." Bell Journal of Economics 2, 3.21.

Stratmann, Thomas (2000). "Congressional Voting over Legislative Careers: Shifting Positions and Changing Constraints." American Political Science Review, 94, 3, 665676.

Tahoun, Ahmed, and Laurence Van Lent (2010), "Personal Wealth Interests of Politicians And Government Intervention in the Economy: The Bailout of the US Financial Sector," Working Paper, University of Manchester.

Tetlock, Paul, 2007, Giving content to investor sentiment, The Journal of Finance 62, 1139-1168.

Theriault, Sean M. (2006). "Procedural Polarization in the U.S. Congress," Working Paper, 
University of Texas at Austin.

Washington, Ebonya (2008). "Female Socialization: How Daughters Affect Their Legislator Fathers' Voting on Women's Issues." American Economic Review, 98, 1, 311-332.

Wilson, Daniel, 2011, Fiscal spending jobs multiplier: Evidence from the 2009 American Recovery and Reinvestment Act, Working paper, Federal Reserve Bank of San Francisco. 


\section{Figure 1: Cumulative Abnormal Returns (CARs) to Economic Interest Spread Portfolio}

This figure shows the event-time Cumulative Abnormal Returns (CARs) to portfolios that invest in industries surrounding legislation passage using the economic interests of senators, specifically the voting of interested senators (as defined in Table III), to define the legislation's impact as positive (long) or negative (short) on the given industry. CARs are computed for each side of the portfolio individually using market-adjusted returns. This figure then presents the returns to the spread portfolio of industry CARs (long-short) from 10 days before passage to 6 months following passage of the bill (120 days).

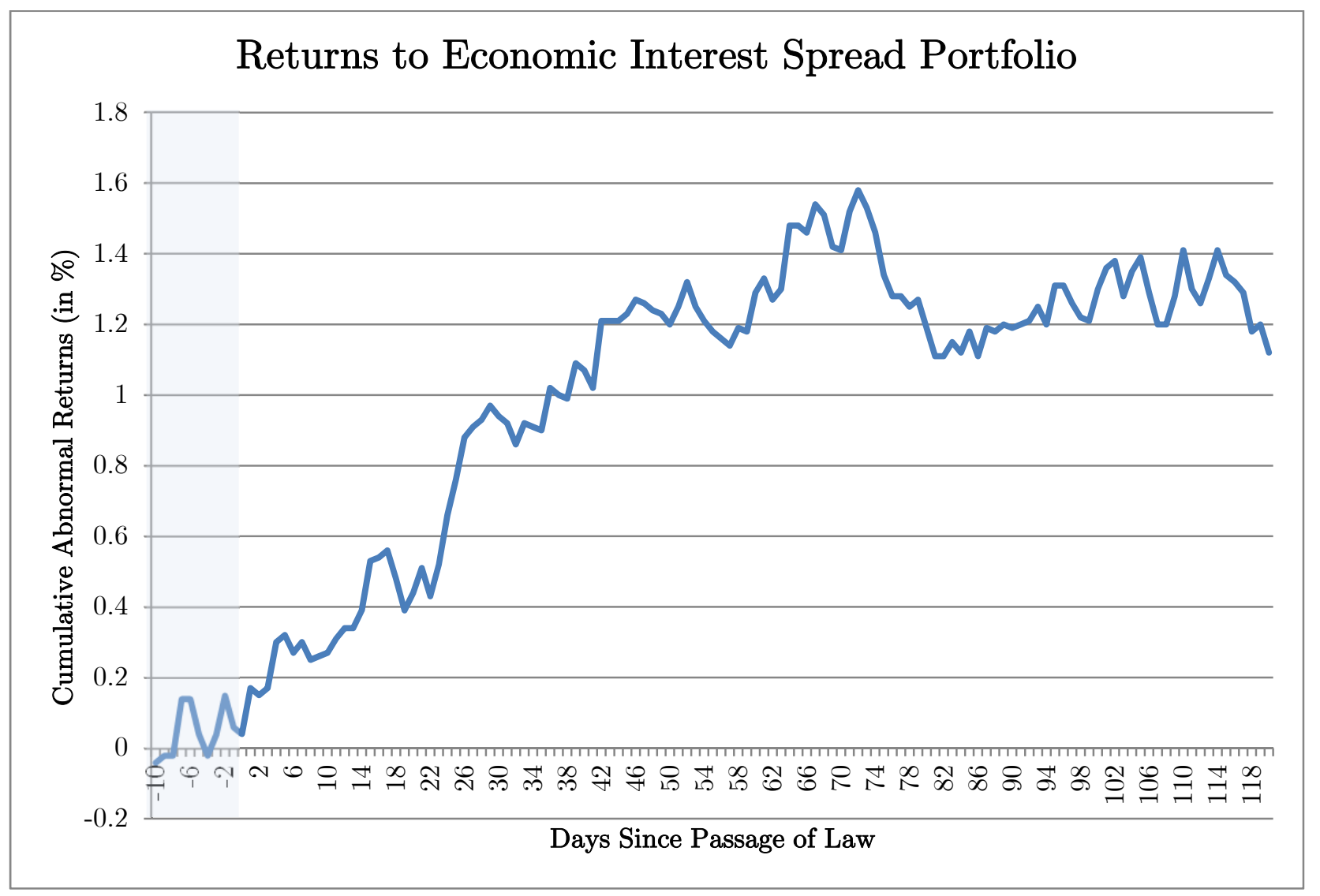




\section{Table I: Summary Statistics}

This table reports summary statistics for the sample. The sample period for the main tests is 199001-200812. We "sign" each bill's expected impact on a given industry by comparing the votes of "interested" Senators on that bill to the votes of "uninterested" Senators on that bill. Interested Senators on a given bill are those where an industry affected by the bill is a "Top 3" industry in that Senator's home state (where industries are ranked within each state by total aggregate firm sales). We then compute an Economic Interest Signing measure as follows: we compute the ratio of positive votes of all interested Senators by dividing their total number of yes votes on a bill by their total number of votes, and compare this to the ratio of positive votes of all uninterested Senators; if the ratio of positive votes by interested Senators is greater than that for uninterested Senators, we call this a "positive" bill for the industry in question, and if the ratio of positive votes for interested Senators is less than that for uninterested Senators, we call this a "negative" bill for the industry.

\begin{tabular}{lccc}
\hline & \multicolumn{3}{c}{ Years 1990-2008 } \\
\cline { 2 - 3 } & Mean & StdDev & Observations \\
\cline { 2 - 4 } Number of Firms in Industry & 144.8 & 153.7 & 6021 \\
Industry Market Capitalization (\$ Millions) & 288.1 & 361.0 & 6021 \\
Industry Value-Weight Monthly Return & 0.775 & 6.33 & 6021 \\
Pass_=1) & 0.821 & 0.383 & 6021 \\
Vote_Yeas & 73.65 & 18.47 & 6021 \\
Vote_Nays & 22.49 & 0.399 & 6021 \\
Bill_Sign_Top3Sales & 0.012 & 0.198 & 6021 \\
Vote_Yeas_Interested_Top3Sales & 7.7 & 10.1 & 6021 \\
Vote_Nays_Interested_Top3Sales & 2.4 & 4.6 & 6021 \\
Vote_Yeas_NotInterested_Top3Sales & 65.9 & 19.7 & 6021 \\
Vote_Nays_NotInterested_Top3Sales & 20.1 & 17.0 & 6021 \\
Bill_Sign_Top5Sales & 0.003 & 0.178 & 6021 \\
Vote_Yeas_Interested_Top5Sales & 12.0 & 14.2 & 6021 \\
Vote_Nays_Interested_Top5Sales & 3.8 & 6.6 & 6021 \\
Vote_Yeas_NotInterested_Top5Sales & 61.6 & 21.2 & 6021 \\
Vote_Nays_NotInterested_Top5Sales & 18.6 & 16.3 & 6021 \\
Bill_Sign_Top10Sales & 0.002 & 0.160 & 6021 \\
Vote_Yeas_Interested_Top10Sales & 20.4 & 19.9 & 6021 \\
Vote_Nays_Interested_Top10Sales & 6.5 & 9.6 & 6021 \\
Vote_Yeas_NotInterested_Top10Sales & 53.3 & 24.0 & 6021 \\
Vote_Nays_NotInterested_Top10Sales & 16.0 & 15.2 & 6021 \\
& & & \\
\hline
\end{tabular}




\section{Table II: Calendar-Time Industry Portfolio Returns: Naïve Bill Signing Approaches}

This table examines the stock returns of industries that are classified as affected by a given piece of legislation. In Panel A we perform a calendar-time portfolio approach as follows: for each final Senate vote on a bill, we examine the stock returns of affected firms following the passage or failure of the bill. We form a "Long" portfolio that buys the firms in each industry that we assign to a bill (weighted by market capitalization) where the bill passes, and a "Short" portfolio that sells the firms in each industry that we assign to a bill (weighted by market capitalization) where the bill fails. Affected stocks do not enter the portfolio until the month following the passage of a bill, and portfolios are rebalanced monthly. This table reports the average monthly "Long-Short" portfolio return for a portfolio that goes buys the "Long" portfolio and sells the "Short" portfolio each month. The "CAPM alpha" is a risk-adjusted return equal to the intercept from a time-series regression of the Long-Short portfolio on the excess return on the value-weight market index (see Fama and French (1996)). The "Fama-French alpha" is a risk-adjusted return equal to the intercept from a time-series regression of the Long-Short portfolio on the excess return on the value-weight market index, the return on the size (SMB) factor, and the return on the value (HML) factor (see Fama and French (1996)). The "Carhart alpha" is a riskadjusted return equal to the intercept from a time-series regression of the Long-Short portfolio on the excess return on the value-weight market index, the return on the size (SMB) factor, the return on the value (HML) factor, and the return on a prior-year return momentum (MOM) factor (see Carhart (1997)). In Panels B and C, we focus on the set of bills that ultimately passed, and attempt to "sign" each bill using different forms of textual analysis. In Panel B, we form a "Long" portfolio that buys the firms in each industry that we assign to a bill (weighted by market capitalization) when the bill contains a below-median number of negative words (defined using the Harvard psychosocial dictionary (see Tetlock (2007)), and a "Short" portfolio that sells the firms in each industry that we assign to a bill (weighted by market capitalization) when the bill contains an above-median number of negative words. Panel $\mathrm{C}$ conducts the identical tests as in Panel B, except that negative words are defined using alternative definition categories (see Loughran and McDonald (2011)). $t$-statistics are shown in parentheses, and $1 \%$, and $5 \%$ statistical significance are indicated with $* *$, and $*$, respectively.

\begin{tabular}{|c|c|c|c|c|}
\hline \multicolumn{5}{|c|}{ Panel A: Industry Returns Around Passage of Legisl } \\
\hline 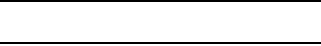 & 2 & uture Returr & & Pre-Returns \\
\hline & $\begin{array}{c}\text { Long (Pass) } \\
\text { Month } t+1 \\
\text { Portfolio } \\
\text { Return }\end{array}$ & $\begin{array}{c}\text { Short (Fail) } \\
\text { Month } t+1 \\
\text { Portfolio } \\
\text { Return }\end{array}$ & $\begin{array}{c}\text { (Long-Short) } \\
\text { Month } t+1 \\
\text { Portfolio Return }\end{array}$ & $\begin{array}{c}\text { (Long-Short) } \\
\text { Month } t-6: t \\
\text { Portfolio Return }\end{array}$ \\
\hline Average returns & 0.49 & 0.57 & -0.09 & 0.02 \\
\hline Standard deviation & 4.36 & 4.46 & 0.33 & 1.53 \\
\hline CAPM alpha & $\begin{array}{c}0.02 \\
(0.12)\end{array}$ & $\begin{array}{c}0.12 \\
(0.42)\end{array}$ & $\begin{array}{c}-0.10 \\
(0.36)\end{array}$ & $\begin{array}{l}0.05 \\
(0.49)\end{array}$ \\
\hline Fama-French alpha & $\begin{array}{c}-0.02 \\
(0.11)\end{array}$ & $\begin{array}{c}0.05 \\
(0.16)\end{array}$ & $\begin{array}{c}-0.07 \\
(0.24)\end{array}$ & $\begin{array}{c}0.03 \\
(0.26)\end{array}$ \\
\hline Carhart alpha & $\begin{array}{c}-0.05 \\
(0.25)\end{array}$ & $\begin{array}{c}-0.02 \\
(0.08)\end{array}$ & $\begin{array}{c}-0.03 \\
(0.09)\end{array}$ & $\begin{array}{c}0.03 \\
(0.31)\end{array}$ \\
\hline
\end{tabular}




\begin{tabular}{|c|c|c|c|c|}
\hline \multicolumn{5}{|c|}{$\begin{array}{c}\text { Panel B: Industry Returns Around Passage of Legislation, Textual Analysis (Harvard } \\
\text { Dictionary) Signing Approach }\end{array}$} \\
\hline & \multicolumn{3}{|c|}{ Future Returns } & Pre-Returns \\
\hline & $\begin{array}{c}\text { Long } \\
\text { (Pass+Harvard } \\
\text { Pos) } \\
\text { Month } t+1 \\
\text { Portfolio Return }\end{array}$ & $\begin{array}{c}\text { Short } \\
\text { (Pass+Harvard } \\
\text { Neg) } \\
\text { Month } t+1 \\
\text { Portfolio } \\
\text { Return }\end{array}$ & $\begin{array}{l}\text { (Long- } \\
\text { Short) } \\
\text { Month } t+1 \\
\text { Portfolio } \\
\text { Return }\end{array}$ & $\begin{array}{l}\text { (Long- } \\
\text { Short) } \\
\text { Month } t-6: t \\
\text { Portfolio } \\
\text { Return }\end{array}$ \\
\hline Average returns & 0.21 & 0.30 & -0.09 & -0.09 \\
\hline Standard deviation & 4.87 & 5.01 & 2.85 & 1.29 \\
\hline CAPM alpha & $\begin{array}{r}-0.23 \\
(1.07)\end{array}$ & $\begin{array}{l}-0.14 \\
(0.56)\end{array}$ & $\begin{array}{r}-0.09 \\
(0.33)\end{array}$ & $\begin{array}{l}-0.10 \\
(1.09)\end{array}$ \\
\hline Fama-French alpha & $\begin{array}{r}-0.25 \\
(1.17)\end{array}$ & $\begin{array}{l}-0.15 \\
(0.64)\end{array}$ & $\begin{array}{l}-0.10 \\
(0.34)\end{array}$ & $\begin{array}{r}-0.09 \\
(0.95)\end{array}$ \\
\hline Carhart alpha & $\begin{array}{l}-0.14 \\
(0.66)\end{array}$ & $\begin{array}{r}-0.28 \\
(1.16)\end{array}$ & $\begin{array}{l}0.14 \\
(0.49)\end{array}$ & $\begin{array}{l}-0.07 \\
(0.81)\end{array}$ \\
\hline
\end{tabular}

Panel C: Industry Returns Around Passage of Legislation, Textual Analysis (Alternate Dictionary) Signing Approach

\begin{tabular}{|c|c|c|c|c|}
\hline & \multicolumn{3}{|c|}{ Future Returns } & \multirow[b]{2}{*}{$\begin{array}{c}\text { Pre-Returns } \\
\\
\text { (Long-Short) } \\
\text { Month } t-6: t \\
\text { Portfolio } \\
\text { Return }\end{array}$} \\
\hline & $\begin{array}{c}\text { Long } \\
\text { (Pass+Alternate } \\
\text { Pos) } \\
\text { Month } t+1 \\
\text { Portfolio Return }\end{array}$ & $\begin{array}{c}\text { Short } \\
\text { (Pass+Alternate } \\
\text { Neg) } \\
\text { Month } t+1 \\
\text { Portfolio } \\
\text { Return }\end{array}$ & $\begin{array}{l}\text { (Long-Short) } \\
\text { Month } t+1 \\
\text { Portfolio } \\
\text { Return }\end{array}$ & \\
\hline Average returns & 0.45 & 0.52 & -0.07 & 0.02 \\
\hline Standard deviation & 4.91 & 5.06 & 3.25 & 1.55 \\
\hline CAPM alpha & $\begin{array}{r}-0.12 \\
(0.58)\end{array}$ & $\begin{array}{c}-0.04 \\
(0.14)\end{array}$ & $\begin{array}{c}-0.08 \\
(0.27)\end{array}$ & $\begin{array}{c}0.02 \\
(0.23)\end{array}$ \\
\hline Fama-French alpha & $\begin{array}{c}-0.15 \\
(0.75)\end{array}$ & $\begin{array}{c}-0.20 \\
(0.77)\end{array}$ & $\begin{array}{c}0.05 \\
(0.15)\end{array}$ & $\begin{array}{c}0.07 \\
(0.62)\end{array}$ \\
\hline Carhart alpha & $\begin{array}{c}-0.04 \\
(0.18)\end{array}$ & $\begin{array}{c}-0.22 \\
(0.79)\end{array}$ & $\begin{array}{c}0.18 \\
(0.55)\end{array}$ & $\begin{array}{c}0.07 \\
(0.62)\end{array}$ \\
\hline
\end{tabular}




\section{Table III: Calendar-Time Industry Portfolio Returns: Economic Interest Signing}

This table examines the stock returns of industries that are classified as affected by a given piece of legislation, after that given piece of legislation passes, for the subset of bills that are passed by the Senate. We perform a calendar-time portfolio approach as follows: for each final Senate vote on a bill that ultimately passes, we examine the stock returns of affected firms following the passage of the bill. We "sign" each bill's expected impact on a given industry by comparing the votes of "interested" Senators on that bill to the votes of "uninterested" Senators on that bill. Interested Senators on a given bill are those where an industry affected by the bill is a "Top 3" industry in that Senator's home state (where industries are ranked within each state by total aggregate firm sales). We then compute an Economic Interest Signing measure as follows: we compute the ratio of positive votes of all interested Senators by dividing their total number of yes votes on a bill by their total number of votes, and compare this to the ratio of positive votes of all uninterested Senators; if the ratio of positive votes by interested Senators is greater than that for uninterested Senators, we call this a "positive" bill for the industry in question, and if the ratio of positive votes for interested Senators is less than that for uninterested Senators, we call this a "negative" bill for the industry. We then form a "Long" portfolio that buys the firms in each industry that we assign to a bill (weighted by market capitalization) where the Economic Interest Signing measure is positive, and a "Short" portfolio that sells the firms in each industry that we assign to a bill (weighted by market capitalization) where the Economic Interest Signing measure is negative. In Panel A, affected stocks do not enter the portfolio until the month following the passage of a bill, and portfolios are rebalanced monthly. In Panel B, affected stocks enter the portfolio in the month of the passage of a bill, and portfolios are rebalanced monthly. In Panel C, affected stocks enter the portfolio 6 months prior to the passage of a bill, and stay in the portfolio until the month prior to the passage of the bill. This table reports the average monthly "Long-Short" portfolio return for a portfolio that goes buys the "Long" portfolio and sells the "Short" portfolio each month. The "CAPM alpha" is a risk-adjusted return equal to the intercept from a time-series regression of the Long-Short portfolio on the excess return on the value-weight market index (see Fama and French (1996). The "Fama-French alpha" is a risk-adjusted return equal to the intercept from a timeseries regression of the Long-Short portfolio on the excess return on the value-weight market index, the return on the size (SMB) factor, and the return on the value (HML) factor (see Fama and French (1996)). The "Carhart alpha" is a riskadjusted return equal to the intercept from a time-series regression of the Long-Short portfolio on the excess return on the value-weight market index, the return on the size (SMB) factor, the return on the value (HML) factor, and the return on a prior-year return momentum (MOM) factor (see Carhart (1997)). t-statistics are shown in parentheses, and 1\%, 5\%, and $10 \%$ statistical significance are indicated with $* * *, * *$, and $*$, respectively.

\begin{tabular}{|c|c|c|c|}
\hline & \multicolumn{3}{|c|}{ Future Returns } \\
\hline & $\begin{array}{c}\text { Long } \\
\text { (Pass+RelSenPos) } \\
\text { Month } t+1 \\
\text { Portfolio Return } \\
\end{array}$ & $\begin{array}{c}\text { Short } \\
\text { (Pass+RelSenNeg) } \\
\text { Month } t+1 \\
\text { Portfolio } \\
\text { Return } \\
\end{array}$ & $\begin{array}{c}\text { (Long-Short) } \\
\text { Month } t+1 \text { Portfolio } \\
\text { Return }\end{array}$ \\
\hline Average returns & 0.63 & -0.14 & 0.76 \\
\hline Standard deviation & 4.63 & 5.40 & 3.84 \\
\hline CAPM alpha & $\begin{array}{l}0.05 \\
(0.28)\end{array}$ & $\begin{array}{c}-0.71^{* *} \\
(2.40)\end{array}$ & $\begin{array}{c}0.76^{* *} \\
(2.44)\end{array}$ \\
\hline Fama-French alpha & $\begin{array}{c}0.01 \\
(0.06)\end{array}$ & $\begin{array}{c}-0.83^{* * *} \\
(3.07)\end{array}$ & $\begin{array}{c}0.84^{* * *} \\
(2.83)\end{array}$ \\
\hline Carhart alpha & $\begin{array}{c}0.14 \\
(0.77)\end{array}$ & $\begin{array}{c}-0.78^{* * *} \\
(2.80)\end{array}$ & $\begin{array}{c}0.92^{* * *} \\
(3.01)\end{array}$ \\
\hline
\end{tabular}




\begin{tabular}{|c|c|c|c|}
\hline \multicolumn{4}{|c|}{$\begin{array}{c}\text { Panel B: Industry Returns Around Passage of Legislation, Economic Interest Signing } \\
\text { Vote Month Returns }\end{array}$} \\
\hline & $\begin{array}{c}\text { Long } \\
\text { (Pass+RelSenPos) } \\
\text { Month } t \text { Portfolio } \\
\text { Return }\end{array}$ & $\begin{array}{c}\text { Short } \\
\text { (Pass+RelSenNeg) } \\
\text { Month } t \text { Portfolio } \\
\text { Return }\end{array}$ & $\begin{array}{c}\text { (Long-Short) } \\
\text { Month } t \text { Portfolio } \\
\text { Return }\end{array}$ \\
\hline Average returns & 0.33 & 0.33 & -0.01 \\
\hline Standard deviation & 4.92 & 4.63 & 3.65 \\
\hline CAPM alpha & $\begin{array}{l}-0.14 \\
(0.61)\end{array}$ & $\begin{array}{l}0.10 \\
(0.37)\end{array}$ & $\begin{array}{l}-0.04 \\
(0.13)\end{array}$ \\
\hline Fama-French alpha & $\begin{array}{l}-0.26 \\
(1.29)\end{array}$ & $\begin{array}{l}-0.20 \\
(0.78)\end{array}$ & $\begin{array}{l}-0.06 \\
(0.19)\end{array}$ \\
\hline Carhart alpha & $\begin{array}{r}-0.16 \\
(0.78)\end{array}$ & $\begin{array}{r}-0.29 \\
(1.06)\end{array}$ & $\begin{array}{l}0.13 \\
(0.43)\end{array}$ \\
\hline
\end{tabular}

\begin{tabular}{|c|c|c|c|}
\hline \multicolumn{4}{|c|}{$\begin{array}{r}\text { Panel C: Industry Returns Around Passage of Legislation, Econo } \\
\text { Pre-Vote Returns }\end{array}$} \\
\hline & $\begin{array}{c}\text { Long } \\
\text { (Pass+RelSenPos) } \\
\text { Month } t-6: t-1 \\
\text { Portfolio Return } \\
\end{array}$ & $\begin{array}{c}\text { Short } \\
\text { (Pass+RelSenNeg) } \\
\text { Month } t-6: t \\
\text { Portfolio } \\
\text { Return } \\
\end{array}$ & $\begin{array}{c}\text { (Long-Short) } \\
\text { Month } t \text {-6:t-1 } \\
\text { Portfolio Return }\end{array}$ \\
\hline Average returns & 0.75 & 0.85 & -0.10 \\
\hline Standard deviation & 4.00 & 4.21 & 1.82 \\
\hline CAPM alpha & $\begin{array}{l}-0.07 \\
(0.66)\end{array}$ & $\begin{array}{l}0.04 \\
(0.27)\end{array}$ & $\begin{array}{l}-0.10 \\
(0.84)\end{array}$ \\
\hline Fama-French alpha & $\begin{array}{l}-0.21^{* *} \\
(-2.42)\end{array}$ & $\begin{array}{l}-0.04 \\
(0.28)\end{array}$ & $\begin{array}{l}-0.17 \\
(1.42)\end{array}$ \\
\hline Carhart alpha & $\begin{array}{c}-0.18^{* *} \\
(2.06)\end{array}$ & $\begin{array}{l}0.03 \\
(0.27)\end{array}$ & $\begin{array}{c}-0.22^{*} \\
(1.74)\end{array}$ \\
\hline
\end{tabular}




\section{Table IV: Cross-Sectional Regressions}

This table reports Fama-MacBeth cross-sectional predictive regressions of future value-weight industry returns on an economic interest signing measure and various industry-level characteristics, from 1989-2008. The economic interest signing approach is described in Table III. The dependent variable in each is future onemonth returns in month $t+1(\mathrm{RET})$. The variable of interest in these regressions is Interested Vote. To construct Interested Vote we "sign" each bill's expected impact on a given industry by comparing the votes of "interested" Senators on that bill to the votes of "uninterested" Senators on that bill. Interested Vote is the difference between the two (so positive when interested Senators on the given bill vote more positively than uninterested Senators, and negative when they vote more negatively). We include various controls on the right-hand side of these regressions for industry-level momentum (i.e., the industry return from months $t-12$ to $t-1$ ), one-month past industry returns, and measures of industry-level average firm size, book-to-market, investment (CAPEX), and ASSETS. t-statistics are shown below the estimates, and 1\%, 5\%, and $10 \%$ statistical significance are indicated with $* * *, * *$, and $*$, respectively.

\begin{tabular}{|c|c|c|c|c|c|}
\hline & (1) & $(2)$ & $(3)$ & (4) & (5) \\
\hline Interested Vote & $\begin{array}{c}0.025^{* * *} \\
\quad(3.03)\end{array}$ & $\begin{array}{c}0.032^{* * *} \\
(2.85)\end{array}$ & $\begin{array}{c}0.036^{* *} \\
(2.45)\end{array}$ & $\begin{array}{c}0.033^{* *} \\
(2.47)\end{array}$ & $\begin{array}{c}0.037^{* *} \\
(2.30)\end{array}$ \\
\hline Industry Avg. Size & & $\begin{array}{c}0.000 \\
(0.32)\end{array}$ & $\begin{array}{c}0.000 \\
(0.24)\end{array}$ & $\begin{array}{c}-0.001 \\
(0.83)\end{array}$ & $\begin{array}{c}0.000 \\
(0.39)\end{array}$ \\
\hline Industry Avg. Book-to-Market & & & $\begin{array}{c}-2.014 \\
(1.12)\end{array}$ & $\begin{array}{c}-0.839 \\
(0.52)\end{array}$ & $\begin{array}{c}0.298 \\
(0.19)\end{array}$ \\
\hline 1-Month Lagged Ind. Return ${ }_{t-1}$ & & & & $\begin{array}{c}0.033^{* *} \\
(1.98)\end{array}$ & $\begin{array}{l}0.025 \\
(1.48)\end{array}$ \\
\hline 12-Month Lagged Return ${ }_{t-12: t-2}$ & & & & $\begin{array}{c}0.018^{* * *} \\
\quad(3.15)\end{array}$ & $\begin{array}{c}0.015^{* * *} \\
\quad(2.66)\end{array}$ \\
\hline Industry Avg. CAPEX & & & & & $\begin{array}{c}0.000 \\
(0.61)\end{array}$ \\
\hline Industry Avg. ASSETS & & & & & $\begin{array}{l}0.000 \\
(0.65)\end{array}$ \\
\hline Number of observations & 396 & 299 & 299 & 287 & 287 \\
\hline
\end{tabular}




\section{Table V: Concentrated Senator Interests}

This table reports calendar-time portfolio tests as in Table III. The Long-Short portfolio tests are computed exactly as in Table III except that the Economic Interest Signing measure described in Table III is refined here as follows. Rather than looking at all interested Senators, we focus here only on the voting behavior of Senator's whose largest industry (by market capitalization) represents an above-median (in Panel A) level of concentration in that state relative to all other states that have that industry during that time period. Concentration is measured as the share of a state's total market cap that is made up of the industry in question. Thus we "sign" each bill's expected impact on a given industry by comparing the votes of this subset of "interested" Senators on that bill to the votes of all other Senators on that bill. We then compute the revised Economic Interest Signing measure exactly as in Table III. In Panel A, the concentration threshold we employ is above-median, and in Panel B the concentration threshold we employ is 80 percent. This table reports the average monthly "Long-Short" portfolio return for a portfolio that goes buys the "Long" portfolio and sells the "Short" portfolio each month. The "CAPM alpha" is a risk-adjusted return equal to the intercept from a time-series regression of the Long-Short portfolio on the excess return on the value-weight market index (see Fama and French (1996). The "Fama-French alpha" is a risk-adjusted return equal to the intercept from a time-series regression of the Long-Short portfolio on the excess return on the value-weight market index, the return on the size (SMB) factor, and the return on the value (HML) factor (see Fama and French (1996)). The "Carhart alpha" is a risk-adjusted return equal to the intercept from a time-series regression of the Long-Short portfolio on the excess return on the value-weight market index, the return on the size (SMB) factor, the return on the value (HML) factor, and the return on a prior-year return momentum (MOM) factor (see Carhart (1997)). t-statistics are shown in parentheses, and 1\%, and $5 \%$ statistical significance are indicated with ${ }^{* *}$, and ${ }^{*}$, respectively.

\begin{tabular}{|c|c|c|c|}
\hline \multicolumn{4}{|c|}{ Economic Interest Signing for Senators with Concentrated Interests } \\
\hline & $\begin{array}{c}\text { Long } \\
\text { Month } t+1 \text { Portfolio } \\
\text { Return }\end{array}$ & $\begin{array}{c}\text { Short Month } t+1 \\
\text { Portfolio } \\
\text { Return }\end{array}$ & $\begin{array}{c}\text { (Long-Short) } \\
\text { Month } t+1 \\
\text { Portfolio } \\
\text { Return }\end{array}$ \\
\hline \multicolumn{4}{|c|}{ Panel A: Top 1 MktCap (>50\% Concentrated) } \\
\hline Raw returns & $\begin{array}{c}0.23 \\
(0.50)\end{array}$ & $\begin{array}{r}-0.50 \\
(1.01)\end{array}$ & $\begin{array}{c}0.74^{* *} \\
(1.97)\end{array}$ \\
\hline CAPM alpha & $\begin{array}{l}-0.22 \\
(0.79)\end{array}$ & $\begin{array}{c}-0.96^{* * *} \\
(2.99)\end{array}$ & $\begin{array}{c}0.74^{* *} \\
(1.97)\end{array}$ \\
\hline Fama-French alpha & $\begin{array}{c}-0.21 \\
(0.76)\end{array}$ & $\begin{array}{c}-0.88^{* * *} \\
(2.94)\end{array}$ & $\begin{array}{l}0.67^{*} \\
(1.84)\end{array}$ \\
\hline Carhart alpha & $\begin{array}{l}-0.09 \\
(0.31)\end{array}$ & $\begin{array}{c}-1.06^{* * *} \\
(3.43)\end{array}$ & $\begin{array}{c}0.97^{* * *} \\
(2.63)\end{array}$ \\
\hline \multicolumn{4}{|c|}{ Panel B: Top 1 MktCap (>80\% Concentrated) } \\
\hline Raw returns & $\begin{array}{c}0.18 \\
(0.35)\end{array}$ & $\begin{array}{l}-0.73 \\
(1.28)\end{array}$ & $\begin{array}{l}0.92^{* *} \\
(2.13)\end{array}$ \\
\hline CAPM alpha & $\begin{array}{l}-0.11 \\
(0.38)\end{array}$ & $\begin{array}{c}-1.03^{* * *} \\
(2.96)\end{array}$ & $\begin{array}{c}0.91^{* *} \\
(2.12)\end{array}$ \\
\hline Fama-French alpha & $\begin{array}{l}-0.10 \\
(0.32)\end{array}$ & $\begin{array}{c}-0.94^{* * *} \\
(2.90)\end{array}$ & $\begin{array}{c}0.84^{* *} \\
(1.99)\end{array}$ \\
\hline Carhart alpha & $\begin{array}{c}0.24 \\
(0.74)\end{array}$ & $\begin{array}{l}-0.81^{* *} \\
(2.28)\end{array}$ & $\begin{array}{l}1.05^{* *} \\
(2.27)\end{array}$ \\
\hline
\end{tabular}




\section{Table VI: Industry Relevance and Home State Firms Only}

This table reports calendar-time portfolio tests as in Table III. In Panel A we exploit variation in our industry assignment procedure. Specifically, we focus solely on cases where the industry in question is the "most" affected of all industries in a given bill; in these cases we only use these industries to compute our industry-level value-weighted return. In Panel B we refine this measure even further by only including the returns of those firms in a given industry who happen to be also located in one of the "interested" Senators home states. This table reports the average monthly "Long-Short" portfolio return for a portfolio that goes buys the "Long" portfolio and sells the "Short" portfolio each month. The "CAPM alpha" is a risk-adjusted return equal to the intercept from a time-series regression of the Long-Short portfolio on the excess return on the value-weight market index (see Fama and French (1996). The "Fama-French alpha" is a risk-adjusted return equal to the intercept from a time-series regression of the Long-Short portfolio on the excess return on the value-weight market index, the return on the size (SMB) factor, and the return on the value (HML) factor (see Fama and French (1996)). The "Carhart alpha" is a risk-adjusted return equal to the intercept from a time-series regression of the Long-Short portfolio on the excess return on the value-weight market index, the return on the size (SMB) factor, the return on the value (HML) factor, and the return on a prior-year return momentum (MOM) factor (see Carhart (1997)). $t$-statistics are shown in parentheses, and 1\%, and $5 \%$ statistical significance are indicated with ${ }^{* *}$, and $*$, respectively.

\begin{tabular}{|c|c|c|c|}
\hline \multicolumn{4}{|c|}{ Variation in Industry Relevance and Firms Affected } \\
\hline & $\begin{array}{c}\text { Long } \\
\text { Month } t+1 \text { Portfolio } \\
\text { Return }\end{array}$ & $\begin{array}{c}\text { Short Month } t+1 \\
\text { Portfolio } \\
\text { Return }\end{array}$ & $\begin{array}{c}\text { (Long-Short) } \\
\text { Month } t+1 \\
\text { Portfolio Return }\end{array}$ \\
\hline \multicolumn{4}{|c|}{ Panel A: Only Focus on Industries Mentioned Most Prominently in Bill } \\
\hline Raw returns & $\begin{array}{l}0.41 \\
(0.69)\end{array}$ & $\begin{array}{r}-0.60 \\
(1.08)\end{array}$ & $\begin{array}{c}1.01^{* *} \\
(2.05)\end{array}$ \\
\hline CAPM alpha & $\begin{array}{l}-0.25 \\
(0.62)\end{array}$ & $\begin{array}{l}-1.20^{* * *} \\
(2.76)\end{array}$ & $\begin{array}{l}0.95^{*} \\
(1.94)\end{array}$ \\
\hline Fama-French alpha & $\begin{array}{r}-0.26 \\
(0.76)\end{array}$ & $\begin{array}{c}-1.19^{* * *} \\
(3.08)\end{array}$ & $\begin{array}{l}0.92^{*} \\
(1.94)\end{array}$ \\
\hline Carhart alpha & $\begin{array}{r}-0.09 \\
(0.24)\end{array}$ & $\begin{array}{c}-1.38^{* * *} \\
(3.55)\end{array}$ & $\begin{array}{c}1.30^{* * *} \\
(2.78)\end{array}$ \\
\hline \multicolumn{4}{|c|}{$\begin{array}{l}\text { Panel B: Only Focus on Industries Mentioned Most Prominently in Bill and Compute } \\
\text { Industry Returns Only Based on Firms Located in Interested Senator's Home State }\end{array}$} \\
\hline Raw returns & $\begin{array}{r}1.23 \\
(1.40)\end{array}$ & $\begin{array}{r}-0.56 \\
(0.58)\end{array}$ & $\begin{array}{c}1.79^{* *} \\
(1.96)\end{array}$ \\
\hline CAPM alpha & $\begin{array}{c}0.19 \\
(0.25)\end{array}$ & $\begin{array}{c}-1.78^{* *} \\
(2.33)\end{array}$ & $\begin{array}{c}1.97^{* *} \\
(2.11)\end{array}$ \\
\hline Fama-French alpha & $\begin{array}{l}0.29 \\
(0.45)\end{array}$ & $\begin{array}{c}-1.71^{* *} \\
(2.29)\end{array}$ & $\begin{array}{c}2.01^{* *} \\
(2.16)\end{array}$ \\
\hline Carhart alpha & $\begin{array}{l}0.44 \\
(0.65)\end{array}$ & $\begin{array}{c}-1.40^{*} \\
(1.81)\end{array}$ & $\begin{array}{l}1.84^{*} \\
(1.89)\end{array}$ \\
\hline
\end{tabular}




\section{Table VII: Bill Complexity}

This table reports calendar-time portfolio tests as in Table III. In this table we exploit variation in the complexity of bills. Specifically, in Panel A we focus solely on complex bills, i.e. bills that have been voted on more times than the median bill (the median number of votes on a bill is 2). In Panel B we focus on noncomplex bills, i.e., the complement to the set of complex bills in Panel A. This table reports the average monthly "Long-Short" portfolio return for a portfolio that goes buys the "Long" portfolio and sells the "Short" portfolio each month. The "CAPM alpha" is a risk-adjusted return equal to the intercept from a time-series regression of the Long-Short portfolio on the excess return on the value-weight market index (see Fama and French (1996). The "Fama-French alpha" is a risk-adjusted return equal to the intercept from a time-series regression of the Long-Short portfolio on the excess return on the value-weight market index, the return on the size (SMB) factor, and the return on the value (HML) factor (see Fama and French (1996)). The "Carhart alpha" is a risk-adjusted return equal to the intercept from a time-series regression of the LongShort portfolio on the excess return on the value-weight market index, the return on the size (SMB) factor, the return on the value (HML) factor, and the return on a prior-year return momentum (MOM) factor (see Carhart (1997)). t-statistics are shown in parentheses, and $1 \%$, and $5 \%$ statistical significance are indicated with ${ }^{* *}$, and ${ }^{*}$, respectively.

\begin{tabular}{|c|c|c|c|}
\hline \multicolumn{4}{|c|}{ Variation in Bill Complexity } \\
\hline & $\begin{array}{c}\text { Long } \\
\text { Month } t+1 \text { Portfolio } \\
\text { Return }\end{array}$ & $\begin{array}{c}\text { Short Month } t+1 \\
\text { Portfolio } \\
\text { Return }\end{array}$ & $\begin{array}{c}\text { (Long-Short) } \\
\text { Month } t+1 \\
\text { Portfolio Return }\end{array}$ \\
\hline \multicolumn{4}{|c|}{ Panel A: Complex Bills Only } \\
\hline \multirow[t]{2}{*}{ Raw returns } & 0.28 & -0.57 & $0.85^{* *}$ \\
\hline & $(0.54)$ & $(-1.07)$ & $(2.19)$ \\
\hline \multirow[t]{2}{*}{ CAPM alpha } & 0.18 & $-0.68^{* *}$ & $0.85^{* *}$ \\
\hline & $(0.63)$ & $(-2.17)$ & $(2.19)$ \\
\hline \multirow[t]{2}{*}{ Fama-French alpha } & 0.08 & $-0.74^{* *}$ & $0.82^{* *}$ \\
\hline & $(0.30)$ & $(-2.39)$ & $(2.16)$ \\
\hline \multirow[t]{2}{*}{ Carhart alpha } & 0.28 & -0.62 & $0.90^{* *}$ \\
\hline & $(1.04)$ & $(-1.96)$ & $(2.28)$ \\
\hline \multicolumn{4}{|c|}{ Panel B: Non-Complex Bills Only } \\
\hline \multirow[t]{2}{*}{ Raw returns } & 0.41 & 0.23 & 0.18 \\
\hline & $(0.90)$ & $(0.46)$ & $(0.48)$ \\
\hline \multirow[t]{2}{*}{ CAPM alpha } & -0.27 & -0.41 & 0.14 \\
\hline & $(-1.28)$ & $(-1.17)$ & $(0.36)$ \\
\hline \multirow[t]{2}{*}{ Fama-French alpha } & -0.30 & -0.51 & 0.21 \\
\hline & $(-1.49)$ & $(-1.56)$ & $(0.55)$ \\
\hline \multirow[t]{2}{*}{ Carhart alpha } & -0.21 & -0.60 & 0.39 \\
\hline & $(-1.01)$ & $(-1.78)$ & $(1.00)$ \\
\hline
\end{tabular}




\section{Table VIII: Robustness Tests: Sub-periods and Economic Interest Thresholds}

This table reports calendar-time portfolio tests as in Table III. In Panel A, we break the main result from Panel A of Table III into two sub-periods: 199001-199912, and 200001-200812. In Panel B, we broaden the Economic Interest Signing measure described in Table III as follows. Instead of using a Top 3 industry threshold to define whether a Senator is interested in a given bill, we employ a Top 5 and a Top 10 industry threshold (again where industries are ranked within each state by total aggregate firm sales). The Long-Short portfolio tests are computed exactly as in Table III once this change is made to the set of interested Senators. This table reports the average monthly "Long-Short" portfolio return for a portfolio that goes buys the "Long" portfolio and sells the "Short" portfolio each month. The "CAPM alpha" is a risk-adjusted return equal to the intercept from a time-series regression of the Long-Short portfolio on the excess return on the value-weight market index (see Fama and French (1996). The "Fama-French alpha" is a risk-adjusted return equal to the intercept from a time-series regression of the Long-Short portfolio on the excess return on the value-weight market index, the return on the size (SMB) factor, and the return on the value (HML) factor (see Fama and French (1996)). The "Carhart alpha" is a risk-adjusted return equal to the intercept from a time-series regression of the Long-Short portfolio on the excess return on the value-weight market index, the return on the size (SMB) factor, the return on the value (HML) factor, and the return on a prior-year return momentum (MOM) factor (see Carhart (1997)). t-statistics are shown in parentheses, and 1\%, and $5 \%$ statistical significance are indicated with **, and *, respectively.

\begin{tabular}{lccc}
\hline \multicolumn{4}{c}{ Panel A: Portfolio Returns Across Sub-periods } \\
& $\begin{array}{c}\text { Long } \\
t+1 \text { Portfolio } \\
\text { Return }\end{array}$ & $\begin{array}{c}\text { Short Month } t+1 \\
\text { Portfolio } \\
\text { Return }\end{array}$ & $\begin{array}{c}\text { (Long-Short) } \\
\text { Month } t+1 \\
\text { Portfolio } \\
\text { Return }\end{array}$ \\
\hline Early Sub-period: 199001-199912 & $1.38^{* * *}$ & 0.73 & $0.66^{* *}$ \\
\hline Raw returns & $(2.58)$ & $(1.30)$ & $(2.03)$ \\
CAPM alpha & 0.01 & $-0.66^{* *}$ & $0.67^{* *}$ \\
& $(0.03)$ & $(2.09)$ & $(1.99)$ \\
Fama-French alpha & 0.11 & $-0.50^{*}$ & $0.61^{*}$ \\
& $(0.41)$ & $(1.68)$ & $(1.76)$ \\
Carhart alpha & 0.31 & -0.42 & $0.72^{* *}$ \\
& $(1.10)$ & $(1.32)$ & $(1.96)$ \\
\hline Recent Sub-period: 200001-200812 & & $0.86^{*}$ \\
\hline Raw returns & -0.12 & -0.99 & $(1.64)$ \\
& $(0.25)$ & $(1.51)$ & $0.88^{*}$ \\
CAPM alpha & 0.01 & $-0.88^{*}$ & $(1.67)$ \\
Fama-French alpha & $(0.04)$ & $(1.75)$ & $0.80^{*}$ \\
& -0.06 & $-0.86^{*}$ & $(1.63)$ \\
Carhart alpha & $(0.25)$ & $(1.93)$ & $0.82^{*}$ \\
& -0.03 & $-0.85^{*}$ & $(1.69)$ \\
\hline
\end{tabular}




\begin{tabular}{lccc}
\hline \multicolumn{4}{c}{ Panel B: Portfolio Returns For Broader Economic Interest Classifications } \\
\hline & $\begin{array}{c}\text { Long } \\
\text { Month } t+1\end{array}$ & $\begin{array}{c}\text { Port Month } t+1 \\
\text { Portfolio } \\
\text { Return }\end{array}$ & $\begin{array}{c}\text { (Long-Short) } \\
\text { Month } t+1 \\
\text { Portfolio Return }\end{array}$ \\
\hline Top 5 Sales Industry & & & \\
\hline Raw returns & $0.76^{* *}$ & 0.14 & $0.62^{* *}$ \\
& $(2.08)$ & $(0.37)$ & $(2.27)$ \\
CAPM alpha & 0.16 & $-0.44^{*}$ & $0.60^{* *}$ \\
& $(0.88)$ & $(1.72)$ & $(2.20)$ \\
Fama-French alpha & 0.09 & $-0.47^{*}$ & $0.56^{* *}$ \\
& $(0.52)$ & $(1.88)$ & $(2.06)$ \\
Carhart alpha & 0.19 & $-0.43^{*}$ & $0.62^{* *}$ \\
& $(1.08)$ & $(1.65)$ & $(2.20)$ \\
\hline Top 10 Sales Industry & & & 0.21 \\
Raw returns & $0.71^{* *}$ & 0.51 & $(0.80)$ \\
CAPM alpha & $(1.99)$ & $(1.43)$ & 0.17 \\
& 0.08 & -0.09 & $(0.69)$ \\
Fama-French alpha & $(0.47)$ & $(0.42)$ & 0.17 \\
Carhart alpha & 0.00 & -0.17 & $(0.68)$ \\
& $(0.01)$ & $(0.80)$ & 0.05 \\
\hline
\end{tabular}




\section{Table IX: Other Influences: Lobbying}

This table reports calendar-time portfolio tests as in Table III. In addition to our Economic Signing Measure, described in Table III, we add data on lobbying expedenditures. The lobbying data we use (obtained from OpenSecrets.org) is available by industry and by year, since 1999. In Panel A we replicate our main result from Table III over the sample period for which lobbying data is available: 199901-200812. In Panel B we examine the subset of affected industries for which lobbying is most pronounced in a given year (above the $80^{\text {th }}$ percentile of industries in terms of lobbying dollar expenditures This table reports the average monthly "Long-Short" portfolio return for a portfolio that goes buys the "Long" portfolio and sells the "Short" portfolio each month. The "CAPM alpha" is a risk-adjusted return equal to the intercept from a time-series regression of the Long-Short portfolio on the excess return on the value-weight market index (see Fama and French (1996). The "Fama-French alpha" is a risk-adjusted return equal to the intercept from a time-series regression of the Long-Short portfolio on the excess return on the value-weight market index, the return on the size (SMB) factor, and the return on the value (HML) factor (see Fama and French (1996)). The "Carhart alpha" is a risk-adjusted return equal to the intercept from a time-series regression of the LongShort portfolio on the excess return on the value-weight market index, the return on the size (SMB) factor, the return on the value (HML) factor, and the return on a prior-year return momentum (MOM) factor (see Carhart (1997)). t-statistics are shown in parentheses, and $1 \%$, and $5 \%$ statistical significance are indicated with **, and *, respectively.

\begin{tabular}{|c|c|c|c|}
\hline \multicolumn{4}{|c|}{ The Impact of Lobbying on Economic Interest Signing } \\
\hline & $\begin{array}{c}\text { Long } \\
\text { Month } t+1 \text { Portfolio } \\
\text { Return }\end{array}$ & $\begin{array}{c}\text { Short Month } t+1 \\
\text { Portfolio } \\
\text { Return }\end{array}$ & $\begin{array}{l}\text { (Long-Short) } \\
\text { Month } t+1 \\
\text { Portfolio } \\
\text { Return }\end{array}$ \\
\hline \multicolumn{4}{|c|}{ Panel A: Economic Interest Signing over Lobbying Data Sample Period (199901-200812) } \\
\hline Raw returns & $\begin{array}{l}0.18 \\
(0.37)\end{array}$ & $\begin{array}{l}-0.87 \\
(1.45)\end{array}$ & $\begin{array}{l}1.05^{* *} \\
(2.10)\end{array}$ \\
\hline CAPM alpha & $\begin{array}{l}0.06 \\
(0.23)\end{array}$ & $\begin{array}{c}-1.00^{* *} \\
(2.11)\end{array}$ & $\begin{array}{l}1.06^{* *} \\
(2.13)\end{array}$ \\
\hline Fama-French alpha & $\begin{array}{c}-0.05 \\
(0.17)\end{array}$ & $\begin{array}{l}-0.95^{* *} \\
(2.24)\end{array}$ & $\begin{array}{l}0.90^{*} \\
(1.94)\end{array}$ \\
\hline Carhart alpha & $\begin{array}{c}0.08 \\
(0.32)\end{array}$ & $\begin{array}{c}-0.90^{* *} \\
(2.11)\end{array}$ & $\begin{array}{c}0.98^{* *} \\
(2.11)\end{array}$ \\
\hline \multicolumn{4}{|c|}{ Panel B: Economic Interest Signing for High Lobbying Industries Only } \\
\hline Raw returns & $\begin{array}{l}-0.46 \\
(0.77)\end{array}$ & $\begin{array}{c}-1.11^{*} \\
(1.65)\end{array}$ & $\begin{array}{l}0.65 \\
(1.46)\end{array}$ \\
\hline CAPM alpha & $\begin{array}{l}-0.45 \\
(1.27)\end{array}$ & $\begin{array}{c}-1.11^{* *} \\
(2.33)\end{array}$ & $\begin{array}{l}0.65 \\
(1.45)\end{array}$ \\
\hline Fama-French alpha & $\begin{array}{l}-0.44 \\
(1.27)\end{array}$ & $\begin{array}{c}-0.89^{* *} \\
(2.32)\end{array}$ & $\begin{array}{l}0.44 \\
(1.04)\end{array}$ \\
\hline Carhart alpha & $\begin{array}{c}0.04 \\
(0.12)\end{array}$ & $\begin{array}{l}-0.54 \\
(1.36)\end{array}$ & $\begin{array}{l}0.58 \\
(1.27)\end{array}$ \\
\hline
\end{tabular}


Legislating Stock Prices:

Internet Appendix 
In this Appendix we describe in more detail the method and data cut-offs we use to: i.) classify bills into industries (as in Cohen and Malloy (2011)), and ii.) assign bills as positive or negative for the given industries to which it relates.

\section{A.1 Industry Classification, Keywords, and Cut-offs}

As described in the data section, we first download the full text of all bills jointly from the Government Printing Office (GPO) and Congress's Thomas database. We then parse each bill's entire text, and use a list of matching words to classify each bill into the industries to which it applies. Table A1 displays the words we use to classify into the Fama-French 49 industries, for three sample industries. We are happy to provide the entire list upon request, for all 49 industries (but including them all in the appendix table made this a 13 page table). Again, the Fama-French 49 industries are somewhat analogous to the SIC 2 digit industry classification, with some improvements and aggregations of similar SIC 2 sub-industry components. As Table A1 shows, we obviously attempt to use a number of keywords to capture the bill's relevance to a given industry. However, we balance this by not choosing too many keywords to induce false positives. In the table, we include when a given industry (or keyword) was removed because it was capturing too many false positives in the industry assignment process.

To give a few examples, we remove the word "soda" from the "Candy and Soda" industry, as it kept matching with "soda ash" and "soda mountain" from a number of bills, both having nothing to do with the desired industry. As another example, for the "Personal Services Industry," we initially included the keyword "beauty shop." Unfortunately, nearly all of the instances of this keyword in bills refer to the "House Beauty Shop," referencing a (debate about) and the eventual closing of this service in one of the House of Representative buildings, and so we remove this keyword as well.

Another important aspect of this table is that after deciding upon keyword roots, we then go through each extension and conjugation that we see in the bills in order to determine which extensions and conjugations reasonably refer to the given industry. So, for instance, for the "Utilities" industry, we use the keyword root "utilit-." While this matches correctly "utility" and "utilities," it incorrectly picks up "utilize" and "utilitarian," which also appear in bills. We thus remove all of the final two matches from the bill matched 
sample to Utilities through "utilit-." We do this for every keyword root in every industry to ensure that the given keyword root matches to the intended industry.

The last element of the process is then choosing threshold frequencies for each keyword appearing in a given bill relative to that keyword's use across all bills, in order to classify a given bill as referring to that keyword's industry. We use two potential methods for this, the first is the absolute count of the keyword, and the second is the ratio of that word to the entire number of words in the bill. For instance, the word "electricity" has a frequency cut-off of 11 times, representing the $95^{\text {th }}$ percentile of that keyword's distribution amongst bills. We have used cut-offs for both measures ranging from the $75^{\text {th }}-95^{\text {th }}$ percentile, and the results in the paper are unaffected. All results reported in the paper are

for the middle of this range, $85^{\text {th }}$ percentile, using the absolute number of keyword appearances.

The outcome of this process is a match of relevant industries to each bill considered in congress. We believe we have a quite conservative match process, but match fairly definitively $20 \%$ of all bills to a relevant industry (or industries).

\section{A.2 Bill Signing Procedure}

In order to "sign" each bill as either positive or negative for the assigned industries, we examine the voting record of the Senators who have an interest in each of our assigned industries. We establish this by summing up the constituent firms located in each Senator's state (we have used sales, market equity, number of employees, and number of firms, and they are highly correlated and yield nearly identical results in terms of magnitude and significance). Then, for each state, we rank all industries that reside in that state and define "important" industries for that state as those that rank in the top 3 for that year. We assign these for each state in each congress, so again displaying the entire table would be quite large. However, in Table A2 we include a subset of state-industry and congress classifications (again, we are happy to provide the entire table upon request, but including them all made this table over 17 pages). To give an example from the Table A2, in the state of New York during the $110^{\text {th }}$ Congress (2007-2008), the most important industries in the state were Banks, Insurance, and Sales \& Trading. 
Once the important industries for each state are established, we then map these to the voting records of the Senators in each state. We then classify each bill that mentions the given industry as positive or negative for the mentioned industry using the interested Senators' votes. For instance, consider bill S.3044 form the $110^{\text {th }}$ Congress shown in Figures A1 and A2. Figure A1 indicates that this particular bill that was assigned only to the Fama-French industry \#30: Petroleum and Natural Gas, based on the relative frequency of pre-specified keywords in the bill that pertain to this industry. Figure A1 displays the summary text at the top of the bill, which indicates that the bill clearly pertains to the oil and gas industry. Figure A2 then displays the executable program we created to implement our signing procedure for the same bill depicted in Figure A1. The summary text indicates that the goal of this bill was "to provide energy price relief and hold oil companies and other entities accountable for their actions with regard to high energy prices, and for other purposes," so the bill was likely to be perceived as negative for the oil and gas industry. The Petroleum and Natural Gas Industry qualified as an important industry in 8 states (including TX and LA), so the total number of "interested" votes in the bill was 16. Not surprisingly, even though this vote lined up largely along party lines, none of the 6 Republican Senators who voted in favor of the bill were Senators who were "tied" to this industry via constituent interests in their home state (all 8 industry-tied Republicans voted against), and 1 of the 2 Democrats who voted against the bill was Mary Landrieu of Louisiana, a state heavily represented by oil and gas interests (the other Democrat who voted against was Henry Reid from Nevada, a consistent supporter of oil and gas companies); the 6 industry-tied Democrats who voted in favor of the bill did so largely on party and ideological grounds (variables that we control for in our tests).

Specifically, we "sign" each bill's expected impact on a given industry by comparing the votes of "interested" Senators on that bill to the votes of "uninterested" Senators on that bill. Again, interested Senators on a given bill are those where an industry affected by the bill is a "Top 3" industry in that Senator's home state (where industries are ranked within each state by total aggregate firm sales, or total market capitalization). We then compute an Economic Interest Signing measure as follows: we compute the ratio of positive votes of all interested Senators by dividing their total number of yes votes on a bill by their total number of votes, and compare this to the ratio of positive votes of all uninterested 
Senators; if the ratio of positive votes by interested Senators is greater than that for uninterested Senators, we call this a "positive" bill for the industry in question, and if the ratio of positive votes for interested Senators is less than that for uninterested Senators, we call this a "negative" bill for the industry. Our results are very similar regardless of whether we use this ratio difference ("R-R" in Figure A2) measure, or alternative signing measures such as the absolute ratio ("Ratio" in Figure A2, i.e., the percentage of industrytied Senators who vote for the bill), or the relative ratio ("R/R" in Figure A2, i.e., the percentage of industry-tied Senators who vote for the bill divided by the percentage of all Senators who vote for the bill). and the ratio difference ("R-R" in Figure A2, i.e., the percentage of industry-tied Senators who vote for the bill minus the percentage of all Senators who vote for the bill); our results are not sensitive to the particular signing measure we employ. We have also tried within-party signing measures that are computed identically to those above, except aggregated within each party (since many votes are along party lines) and again the results are very similar. 


\section{Table A1: Industry Assignment Keywords and Cut-offs}

This table shows the keywords used in assigning the full text of each bill in our sample to the resultant industries covered by the bill, along with the cut-offs for the percentile in the distribution of that keyword for the entire sample. We assign the given industry to a bill if any one of its keywords is above the $85^{\text {th }}$ percentile cut-off given in the table. We choose a subset of the 49 industries (Fama-French Industry Classification) that we use, as the table would otherwise be prohibitively long. We are happy to provide the entire table of keywords and cut-offs upon request.

\begin{tabular}{|c|c|c|c|}
\hline $\begin{array}{l}\text { Fama-French } \\
\text { Industry \# / } \\
\text { Industry Name }\end{array}$ & Keyword & $\begin{array}{c}\text { Count } \\
\text { Greater Than / Equal } \\
\text { To } \\
\end{array}$ & $\begin{array}{c}\text { Count } \\
\text { Percentile }\end{array}$ \\
\hline 1 - Agriculture & $\begin{array}{l}\text { agricultur- } \\
\text { animal feed } \\
\text { corn } \\
\text { crop(s) } \\
\text { farm(s)(land) } \\
\text { fishing } \\
\text { livestock } \\
\text { wheat }\end{array}$ & $\begin{array}{c}12 \\
7 \\
4 \\
14 \\
11 \\
8 \\
7 \\
8\end{array}$ & $\begin{array}{l}85 \\
85 \\
85 \\
85 \\
85 \\
85 \\
85 \\
85\end{array}$ \\
\hline 26 - Defense & $\begin{array}{l}\text { air force } \\
\text { Ammunition } \\
\text { armed force(s) } \\
\text { army } \\
\text { gun(s)(runners)(powder) } \\
\text { marine corps } \\
\text { military } \\
\text { missile(s) } \\
\text { national guard } \\
\text { navy } \\
\text { ordnance } \\
\text { space vehicle(s) } \\
\text { tanks } \\
\text { weapon(s) }\end{array}$ & $\begin{array}{c}31 \\
15 \\
10 \\
13 \\
8 \\
30 \\
11 \\
23 \\
30 \\
19 \\
7 \\
3 \\
9 \\
15\end{array}$ & $\begin{array}{l}85 \\
85 \\
85 \\
85 \\
85 \\
85 \\
85 \\
85 \\
85 \\
85 \\
85 \\
85 \\
85 \\
85\end{array}$ \\
\hline 48 - Trading & $\begin{array}{l}\text { broker dealer(s) } \\
\text { closed end } \\
\text { commodity broker(s) } \\
\text { financial services firm(s) } \\
\text { investment bank(s) } \\
\text { investment firm(s) } \\
\text { investment management } \\
\text { investment trust(s) } \\
\text { mutual fund(s) } \\
\text { reit(s) } \\
\text { broker-dealer(s) } \\
\text { closed-end } \\
\text { security broker(s) } \\
\text { unit trust(s) }\end{array}$ & $\begin{array}{c}3 \\
2 \\
14 \\
2 \\
8 \\
2 \\
6 \\
12 \\
3 \\
44 \\
\text { No Keyword Count Inf } \\
\text { No Keyword Count Inf } \\
\text { Keyword removed : } \\
\text { keyword, and all appea } \\
\text { No Keyword Count Inf }\end{array}$ & $\begin{array}{l}\qquad 5 \\
\qquad 5 \\
85 \\
85 \\
85 \\
85 \\
85 \\
85 \\
85 \\
85 \\
\text { tion Available } \\
\text { tion Available } \\
2 \text { bills with the } \\
\text { lefinition clauses } \\
\text { tion Available } \\
\end{array}$ \\
\hline
\end{tabular}




\section{Table A2: Industry Assignments by State}

This table shows the 3 most important industries for each state at the beginning, midpoint, and endpoint of our sample. "Importance" is measured by summing up the market equity of all publicly traded firms in each industry residing in a state, and then ranking industries. We thus show below the three largest industries operating in each given state over each Congress. We choose a subset of states and Congresses, as the table would otherwise be prohibitively long. We are happy to provide the entire table of states, industries operating in those states, and most important industries for each state and Congress upon request.

\begin{tabular}{|c|c|c|c|}
\hline State & $\begin{array}{c}\text { Fama-French } \\
\text { Industry \# }\end{array}$ & Industry Name & Congress \\
\hline TX & 30 & Oil & 101 \\
\hline $\mathrm{TX}$ & 31 & Utilities & 101 \\
\hline $\mathrm{TX}$ & 32 & Telecom & 101 \\
\hline $\mathrm{TX}$ & 30 & Oil & 105 \\
\hline $\mathrm{TX}$ & 32 & Telecom & 105 \\
\hline $\mathrm{TX}$ & 35 & Computers & 105 \\
\hline TX & 30 & Oil & 110 \\
\hline $\mathrm{TX}$ & 31 & Utilities & 110 \\
\hline $\mathrm{TX}$ & 32 & Telecom & 110 \\
\hline NY & 45 & Banks & 101 \\
\hline NY & 46 & Insurance & 101 \\
\hline NY & 48 & Trading & 101 \\
\hline NY & 45 & Banks & 105 \\
\hline NY & 46 & Insurance & 105 \\
\hline NY & 48 & Trading & 105 \\
\hline NY & 45 & Banks & 110 \\
\hline NY & 46 & Insurance & 110 \\
\hline NY & 48 & Trading & 110 \\
\hline $\mathrm{CA}$ & 32 & Telecom & 101 \\
\hline $\mathrm{CA}$ & 35 & Computers & 101 \\
\hline $\mathrm{CA}$ & 43 & Retail & 101 \\
\hline $\mathrm{CA}$ & 35 & Computers & 105 \\
\hline $\mathrm{CA}$ & 36 & Software & 105 \\
\hline $\mathrm{CA}$ & 37 & Electronic Equipment & 105 \\
\hline $\mathrm{CA}$ & 35 & Computers & 110 \\
\hline $\mathrm{CA}$ & 36 & Software & 110 \\
\hline $\mathrm{CA}$ & 37 & Electronic Equipment & 110 \\
\hline
\end{tabular}


Figure 1. Congressional Bill Industry Assignment Example

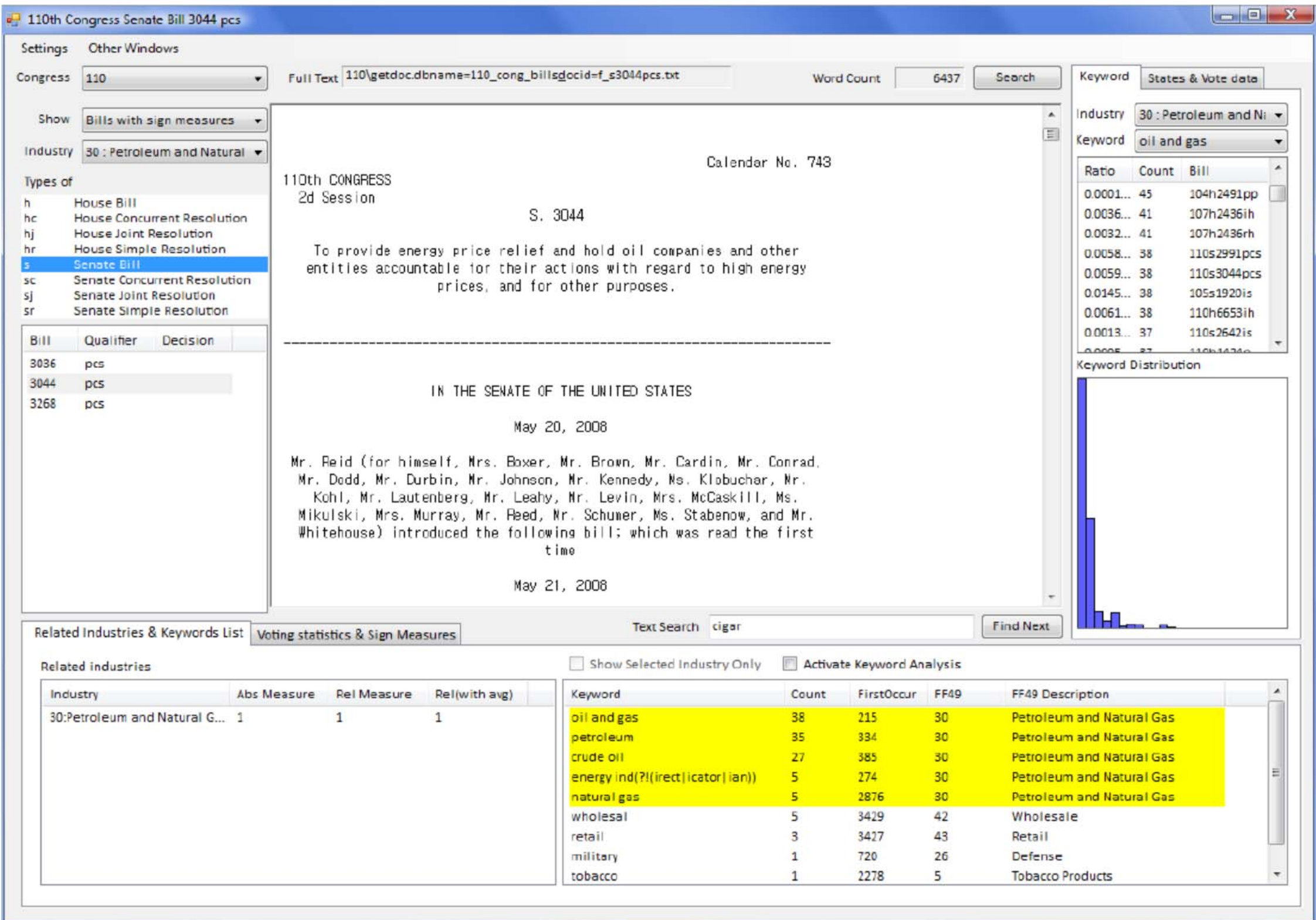


Figure 2. Congressional Bill Positive/Negative Signing Example

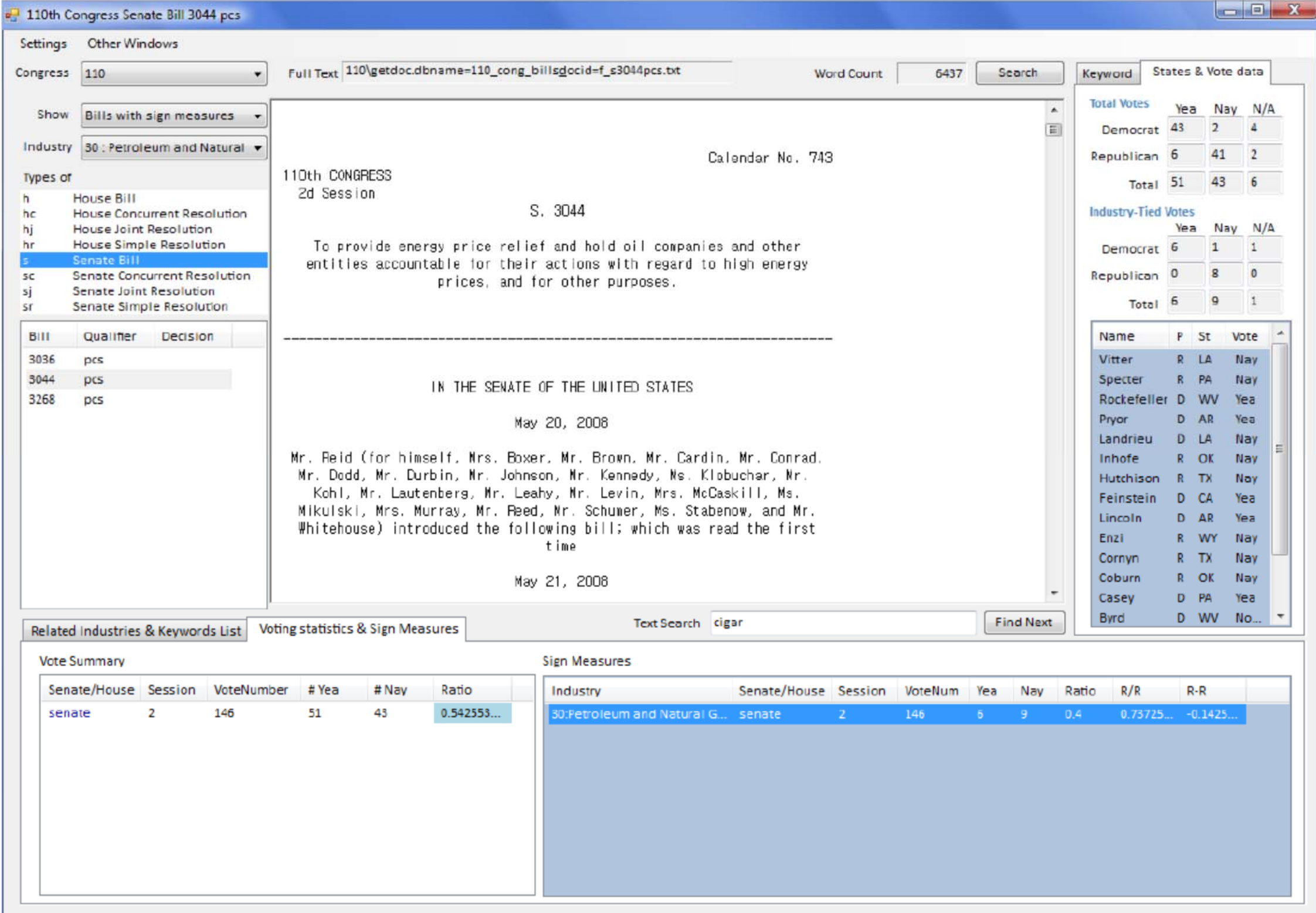

